Atmos. Chem. Phys., 19, 275-294, 2019

https://doi.org/10.5194/acp-19-275-2019

(C) Author(s) 2019. This work is distributed under

the Creative Commons Attribution 4.0 License.

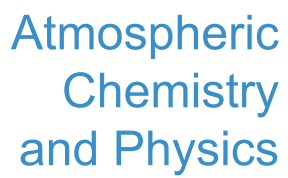

(c) (P)

\title{
CCN measurements at the Princess Elisabeth Antarctica research station during three austral summers
}

\author{
Paul Herenz $^{1,2}$, Heike Wex ${ }^{1}$, Alexander Mangold ${ }^{3}$, Quentin Laffineur ${ }^{3}$, Irina V. Gorodetskaya ${ }^{4,5}$, Zoë L. Fleming ${ }^{6}$, \\ Marios Panagi ${ }^{6}$, and Frank Stratmann ${ }^{1}$ \\ ${ }^{1}$ Leibniz Institute for Tropospheric Research, Leipzig, Germany \\ ${ }^{2}$ Senate Department for the Environment, Transport and Climate Protection, Berlin, Germany \\ ${ }^{3}$ Royal Meteorological Institute of Belgium, Brussels, Belgium \\ ${ }^{4}$ Centre for Environmental and Marine Studies, Department of Physics, University of Aveiro, Aveiro, Portugal \\ ${ }^{5}$ Department of Earth and Environmental Sciences, KU Leuven, Leuven, Belgium \\ ${ }^{6}$ National Centre for Atmospheric Science, Department of Chemistry, University of Leicester, Leicester, UK
}

Correspondence: Heike Wex (wex@tropos.de)

Received: 7 March 2018 - Discussion started: 20 April 2018

Revised: 6 December 2018 - Accepted: 7 December 2018 - Published: 8 January 2019

\begin{abstract}
For three austral summer seasons (2013-2016, each from December to February) aerosol particles arriving at the Belgian Antarctic research station Princess Elisabeth (PE) in Dronning Maud Land in East Antarctica were characterized. This included number concentrations of total aerosol particles $\left(N_{\mathrm{CN}}\right)$ and cloud condensation nuclei $\left(N_{\mathrm{CCN}}\right)$, the particle number size distribution (PNSD), the aerosol particle hygroscopicity, and the influence of the air mass origin on $N_{\mathrm{CN}}$ and $N_{\mathrm{CCN}}$. In general $N_{\mathrm{CN}}$ was found to range from 40 to $6700 \mathrm{~cm}^{-3}$, with a median of $333 \mathrm{~cm}^{-3}$, while $N_{\mathrm{CCN}}$ was found to cover a range between less than 10 and $1300 \mathrm{~cm}^{-3}$ for supersaturations (SSs) between $0.1 \%$ and $0.7 \%$. It is shown that the aerosol is dominated by the Aitken mode, being characterized by a significant amount of small, and therefore likely secondarily formed, aerosol particles, with $94 \%$ and $36 \%$ of the aerosol particles smaller than 90 and $\approx 35 \mathrm{~nm}$, respectively. Measurements of the basic meteorological parameters as well as the history of the air masses arriving at the measurement station indicate that the station is influenced by both marine air masses originating from the Southern Ocean and coastal areas around Antarctica (marine events - MEs) and continental air masses (continental events - CEs). CEs, which were defined as instances when the air masses spent at least $90 \%$ of the time over the Antarctic continent during the last 10 days prior to ar-
\end{abstract}

rival at the measurements station, occurred during $61 \%$ of the time during which measurements were done. CEs came along with rather constant $N_{\mathrm{CN}}$ and $N_{\mathrm{CCN}}$ values, which we denote as Antarctic continental background concentrations. MEs, however, cause large fluctuations in $N_{\mathrm{CN}}$ and $N_{\mathrm{CCN}}$, with low concentrations likely caused by scavenging due to precipitation and high concentrations likely originating from new particle formation (NPF) based on marine precursors. The application of HYSPLIT back trajectories in form of the potential source contribution function (PSCF) analysis indicate that the region of the Southern Ocean is a potential source of Aitken mode particles. On the basis of PNSDs, together with $N_{\mathrm{CCN}}$ measured at an SS of $0.1 \%$, median values for the critical diameter for cloud droplet activation and the aerosol particle hygroscopicity parameter $\kappa$ were determined to be $110 \mathrm{~nm}$ and 1, respectively. For particles larger than $\approx 110 \mathrm{~nm}$ the Southern Ocean together with parts of the Antarctic ice shelf regions were found to be potential source regions. While the former may contribute sea spray particles directly, the contribution of the latter may be due to the emission of sea salt aerosol particles, released from snow particles from surface snow layers, e.g., during periods of high wind speed, leading to drifting or blowing snow. The region of the Antarctic inland plateau, however, was not found to feature a significant source region for aerosol particles in general or 
for cloud condensation nuclei measured at the PE station in the austral summer.

\section{Introduction}

Aerosol particles can be emitted into the atmosphere either directly, e.g., by mechanical processes or combustion, or indirectly, due to nucleation from the gas phase. Under specific conditions, aerosol particles can act as cloud condensation nuclei $(\mathrm{CCN})$ and form cloud droplets. Whether a particle forms a cloud droplet depends on its size and the chemical composition of the particle as well as the surrounding supersaturation (SS). Aerosol particles can influence the climate either directly, by scattering or absorption of solar radiation, or indirectly, due to their impact on cloud formation and cloud properties, e.g., the cloud albedo (Twomey, 1974), or on the lifetime of clouds (Albrecht, 1989; Rosenfeld et al., 2008). The direct effect of aerosol particles is relatively well understood. In contrast to this, the manifold indirect aerosol effects are less understood. The influence of indirect aerosol effects on the global climate and the radiative forcing still features a low confidence level and large uncertainties (IPCC, 2013). The climate impact of aerosol particles is mainly determined by their physical and chemical properties. Investigations of these properties of aerosol particles in general and of $\mathrm{CCN}$ in particular, by means of in situ measurements at various different sites and conditions, are necessary to lower these uncertainties. The Antarctic region is particularly interesting for aerosol particle and $\mathrm{CCN}$ in situ studies for two reasons. Firstly, Antarctica is located far from anthropogenic activities and is one of the most pristine areas on the globe (Hamilton et al., 2014). Thus, it is a favorable environment for studying natural aerosol particle background conditions and processes that prevailed in a preindustrial atmosphere. A more accurate knowledge about preindustrial aerosol processes, conditions and properties, including aerosol-cloud interactions, is important for a reduction of uncertainties of model estimates concerning radiative forcing (Hamilton et al., 2014; Carslaw et al., 2013). Secondly, similar to the Arctic, the Antarctic region is extremely sensitive to climate change. Jacka and Budd (1998) analyzed surface temperature data from 16 stations on the Antarctic continent and 22 stations on Southern Ocean islands and found warming rates of 0.9-1.2 and $0.7-1{ }^{\circ} \mathrm{C}$, respectively. In particular, in the West Antarctic and the Antarctic Peninsula, the warming is several times higher than in other regions (Jacka and Budd, 1998; Vaughan et al., 2003; Kravchenko et al., 2011; IPCC, 2013). The Antarctic sea ice as well as the inland ice sheet are potentially subject to change in such a changing environment. However, at the moment, the Southern Hemisphere has not shown a decrease in the sea ice extent. Parkinson and Cavalieri (2008) and Parkinson and Cavalieri (2012) even found an increasing annual maximum Southern Ocean sea ice ex- tent. Both the sea ice area and the open water area have the potential to emit aerosol particles into the atmosphere. Sea ice is a potential source for sea salt aerosol particles (Huang and Jaeglé, 2017; Yang et al., 2008; Wagenbach et al., 1998) and nitrogen (Dall'Osto et al., 2017), and open sea water may emit sea spray aerosol and precursors for new particle formation (NPF; Liss and Lovelock, 2008; Modini et al., 2015). Therefore, variations in sea ice coverage will likely lead to changes in the nature of aerosol particle sources. There are opposing trends in the ice sheet mass balance across Antarctica. Velicogna and Wahr (2006) and Shepherd et al. (2012, 2018) found that the ice sheets of West Antarctica and the Antarctic Peninsula had lost mass, whereas the East Antarctic ice sheet had gained mass. The gain of ice mass in East Antarctica is also confirmed by Martin-Español et al. (2017), however they found it to be smaller than losses in West Antarctica. As precipitation, which in addition to moisture amounts is also strongly linked to the abundance of $\mathrm{CCN}$ and ice nucleating particles, is the only source of mass gain to the Antarctic ice sheet, it is necessary to study the properties of these aerosol particles as well as their impact on cloud formation and precipitation, sources, sinks, and pathways in the changing environment of Antarctica.

Although Antarctica is a harsh environment where access to field work is difficult, various aerosol particle studies have been conducted at different Antarctic research stations during the last decades. A wide range of topics has already been investigated, including NPF (Koponen et al., 2003; Asmi et al., 2010; Kyrö et al., 2013; Fiebig et al., 2014; Weller et al., 2015), seasonal cycles of number and mass concentrations, as well as size distributions (Koponen et al., 2003; Kim et al., 2017; Fiebig et al., 2014), chemical composition (Wagenbach et al., 1988; Teinila et al., 2000), hygroscopicity (Asmi et al., 2010; Kim et al., 2017; O'Shea et al., 2017), and optical properties of aerosol particles (Fiebig et al., 2014).

In general, there is a yearly trend in particle number concentrations, with maximum values in the austral summer (Kim et al., 2017; Fiebig et al., 2014). Fiebig et al. (2014) concluded that these cycles are common across the Antarctic Plateau (including the Troll research station, $235 \mathrm{~km}$ from the Antarctic coast, which is still $2000 \mathrm{~km}$ away from the South Pole), with free tropospheric air masses contributing to air detected at the ground. The highest particle concentrations found in the austral summer are frequently reported to be due to NPF events (Asmi et al., 2010; Koponen et al., 2003; Kyrö et al., 2013; Weller et al., 2015; Kim et al., 2017). Particles formed during NPF events are likely related to sulfate and compounds containing ammonia that were found in the particulate phase in the submicron size range (Teinila et al., 2000; Wagenbach et al., 1988; Schmale et al., 2013). Precursor gases for NPF can originate from the Southern Ocean (e.g., DMS (dimethylsulfid); Weller et al., 2015; Schmale et al., 2013) and possibly also from other sources, e.g., cyanobacteria in freshwater melt ponds (Kyrö et al., 2013); microbiota from sea ice and the ocean influenced by 
sea ice (Dall'Osto et al., 2017); or the decomposition of excreta from fur seals, seabirds and penguins (Legrand et al., 1998; Schmale et al., 2013).

Newly formed particles were sometimes reported to grow to $\mathrm{CCN}$ size ranges at the Aboa research station, e.g., in Kyrö et al. (2013) and Koponen et al. (2003) (for the latter only in marine air masses), while Weller et al. (2015) reported a maximum size of only $25 \mathrm{~nm}$ for particles grown from NPF for observations at the Neumayer research station. These differing observations were related to a difference in ground cover at the respective measurement sites, which was covered by ice around Neumayer but featured melt ponds around Aboa (Weller et al., 2015).

Sodium chloride, supposedly from sea spray, was found for larger particles (well above $100 \mathrm{~nm}$ ) at Aboa, while the majority of particles was smaller than $100 \mathrm{~nm}$ (Teinila et al., 2000). A case of exceptionally high particle hygroscopicity was connected to air masses originating from a region with sea ice and open water at the coastal Antarctic research station of Halley (O'Shea et al., 2017). Asmi et al. (2010) assumed that particles and nucleating and condensing vapors from the Southern Ocean contribute to particles observed at Aboa and that observed hygroscopic growth factors for particles of 25,50 and $90 \mathrm{~nm}$ were similar to those they reported for ammonium sulfate.

Furthermore, some studies have reported on Antarctic CCN properties, however the locations they cover are limited to the Antarctic Peninsula (DeFelice, 1996; DeFelice et al., 1997; Kim et al., 2017) or the area of the Weddell Sea on the Brunt Ice Shelf (O'Shea et al., 2017). Both locations are part of West Antarctica, and especially the Antarctic Peninsula is mainly influenced by marine air masses that directly originate from the Southern Ocean. To create a more detailed picture of Antarctic CCN, further measurements that can be used to characterize $\mathrm{CCN}$ in the eastern, and especially in the central (inland plateau), part of Antarctica are needed.

To gain further knowledge about aerosol particle, and particularly $\mathrm{CCN}$ properties in East Antarctica, we conducted measurements at the Belgian Antarctic research station Princess Elisabeth (PE) in Dronning Maud Land. For three austral summer seasons (2013-2016, always from December to February) a condensation particle counter (CPC), a cloud condensation nucleus counter (CCNC) and a laser aerosol spectrometer (LAS) were used to simultaneously measure aerosol particle and $\mathrm{CCN}$ properties inside the East Antarctic boundary layer. In addition, the present study introduces meteorological data, collected by an automatic weather station, and precipitation rates derived from a vertically pointing precipitation radar as well as the history of the measured air masses, calculated by means of the Numerical Atmospheric-dispersion Modelling Environment (NAME) and the National Oceanic and Atmospheric Administration (NOAA) HYSPLIT trajectory model. This data set has enabled the study of the variability of the condensation $\mathrm{Nu}$ clei $(\mathrm{CN})$ and $\mathrm{CCN}$ number concentrations to identify their sources, sinks and transport pathways and to analyze the particle hygroscopicity during the austral summer in East Antarctica. The special location of the PE station in the escarpment zone with katabatic winds coming from the Antarctic inland ice sheet further allows insight into aerosol particle and $\mathrm{CCN}$ properties of continental Antarctica.

\section{Experimental procedure and methods}

\subsection{Measuring site and meteorology}

The measurements presented in this study were all performed at the PE station (Fig. 1a) in Dronning Maud Land, East Antarctica $\left(71.95^{\circ} \mathrm{S}, 23.35^{\circ} \mathrm{E} ; 1390 \mathrm{~m}\right.$ a.s.l. - above sea surface level - around $200 \mathrm{~km}$ inland from the Antarctic coast). The PE station is located on the granite ridge of Utsteinen Nunatak in the Dronning Maud Land region of East Antarctica and lies north of the Sør Rondane mountain range, which has peaks of up to an altitude of $3300 \mathrm{~m}$ a.s.l. This area is located in the escarpment zone between the Antarctic inland plateau and the coast, which can be seen in the topographic map of Antarctica in Fig. 1b. A more detailed description of the conditions at the measurement station and its near surroundings is given by Pattyn et al. (2010) and Gorodetskaya et al. (2013). The PE station is designed as a zero-emission station, with power production mainly based on wind and solar energy (see http://www.antarcticstation.org/, last access: 4 January 2019). This reduces local emissions, making the PE station an excellent base for conducting in situ aerosol particle measurements. Nevertheless, general station activities, traffic by skidoos or bulldozers, and irregular diesel generator operation times cause contamination, which is, however, removed from the final data (see Sect. 2.2). The station is inhabited from November to the end of February. During the other months the station and most of its scientific instruments are operated under remote control. As the CCNC used for this study needs an operator on site, we mainly present data collected from December to February during three subsequent austral summers (2013-2016).

The basic meteorological parameters (near-surface air temperature, pressure, relative humidity, wind speed and wind direction) were measured by means of an automatic weather station (AWS; Gorodetskaya et al., 2013; Souverijns et al., 2018) which was located $300 \mathrm{~m}$ east of PE. The snowfall rates $(S)$ were derived from Metek's Micro-Rain-Radar (MRR-2) effective reflectivities $(Z)$, applying an $Z-S$ relationship derived specifically for the PE location (Souverijns et al., 2017). The radar is a vertically pointing $24 \mathrm{GHz}$ precipitation radar operating at PE since January 2010 (Gorodetskaya et al., 2015). Radar $Z$ was estimated from the radar's raw Doppler spectra using the algorithm of Maahn and Kollias (2012) that was specifically designed for MRR snowfall applications. $S$ at the $300 \mathrm{~m}$ a.g.l. level was estimated using a mean $Z-S$ relationship derived by Souverijns et al. 

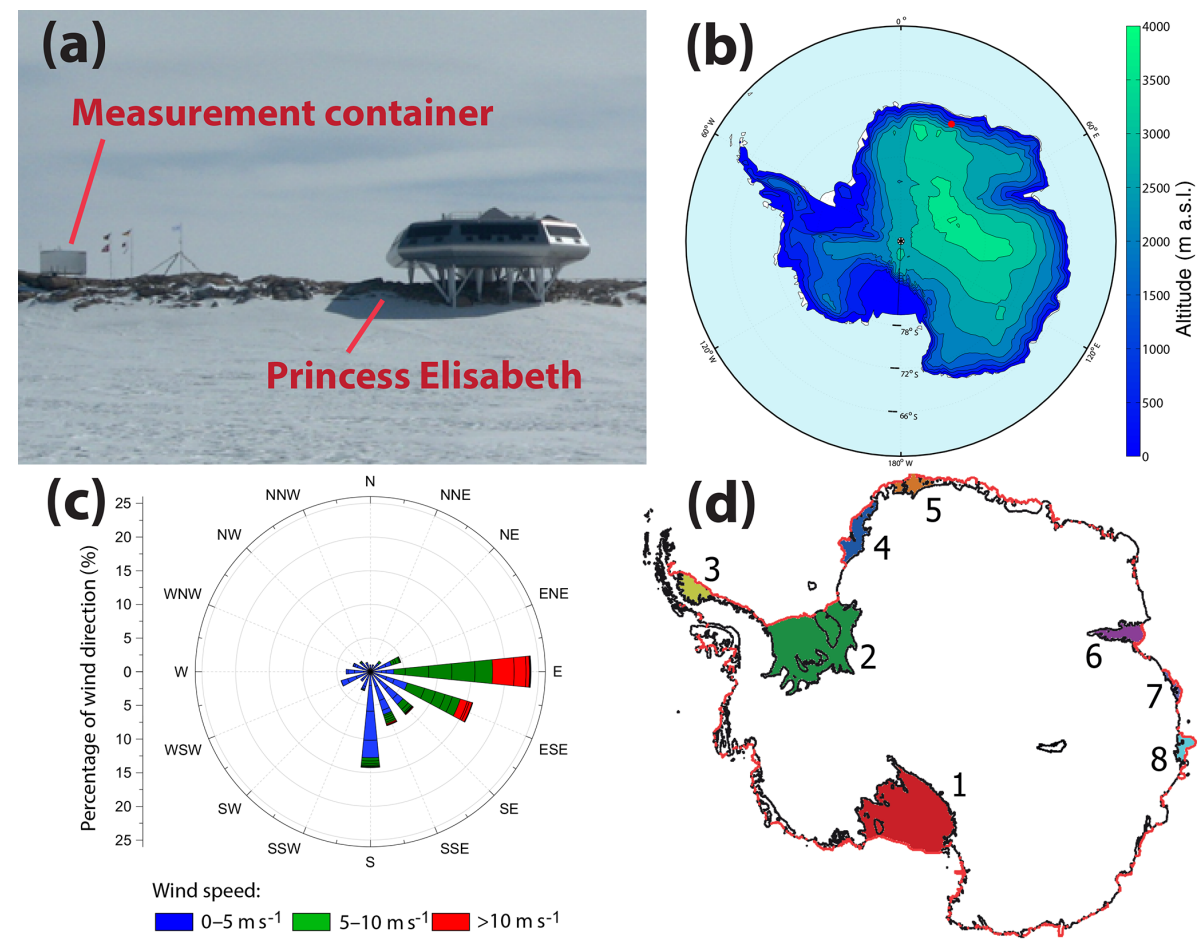

Figure 1. (a) Picture of the Princess Elisabeth research station and the measurement container where the aerosol measurements were performed, both located on the Utsteinen Nunatak ridge (view from east-south-east). (b) Topographic map of Antarctica; the red dot shows the location of PE. This map was created using the Matlab mapping package M_Map. (c) Wind direction and wind speed, depicted as a wind rose for the third measurement period (18 December 2015 to 20 February 2016). (d) Map showing the location of the largest shelf ice regions in Antarctica: (1) Ross, (2) Filchner-Ronne, (3) Larsen C, (4) Riiser-Larsen, (5) Fimbul, (6) Amery, (7) West and (8) Shackleton shelf ice. The black line represents the coast line, and the red line represents the ice edge. This map was created using Matlab and its Antarctic Mapping Tools (Schaffer et al., 2016; Greene et al., 2017).

(2017), which was based on snowfall microphysical measurements at PE. More details about the AWS, the precipitation radar and the estimation of precipitation can be found in Gorodetskaya et al. $(2013,2015)$ and Souverijns et al. (2017), respectively and on the AEROCLOUD website (http://www.aerocloud.be, last access: 4 January 2019). Generally, the meteorological situation at PE is characterized by either synoptic regimes, which usually correspond to strong easterly winds with a sometimes slight northerly component, or a katabatic regime, which is mostly associated with relatively weak south-southeasterly winds (Gorodetskaya et al., 2013; Souverijns et al., 2018).

The two different meteorological situations can be identified based on wind speed and wind direction, which are both depicted in the form of a wind rose in Fig. 1c (exemplarily based on measurements between 18 December 2015 to 10 February 2016 in the third season). The more frequently occurring easterly winds clearly correspond to higher wind speeds, mainly over $5 \mathrm{~m} \mathrm{~s}^{-1}$, whereas the less frequently occurring southerly winds are usually below $5 \mathrm{~m} \mathrm{~s}^{-1}$. Additional meteorological parameters for each year are shown in Fig. 2 as a time series of hourly (gray lines) and daily averaged (red lines) values. The respective seasonal mean val- ues together with the standard deviation, minimum and maximum for the period from 1 December to 20 February are shown in Table 1. The mean values as well as the fluctuation in the meteorological parameters show no large differences between the three measurement periods. Due to the shielding effect of the Sør Rondane Mountains to the south, blocking the katabatic winds from the inland plateau, the climate at $\mathrm{PE}$ is relatively mild for the Antarctic escarpment zone (Gorodetskaya et al., 2013).

\subsection{Instrumentation and data processing}

The total particle number concentration $\left(N_{\mathrm{CN}}\right)$ was measured by a CPC (TSI model 3776), which has a lower cut-off at $3 \mathrm{~nm}$ and was operated at a total flow rate of $1.5 \mathrm{~L} \mathrm{~min}^{-1}$. The CPC was first installed for continuous operation in November 2012. Due to several power outages in the austral winter, data coverage of the winter months was not equal between the years, and the CPC was restarted in the respective austral summers. The last data for this study was measured in May 2016. The inlet tubing for the CPC consisted of a $1 \mathrm{~m}$ long vertical $0.5 \mathrm{in}$. stainless steel tubing (not heated) installed through the roof of the measurement container. In- 
Table 1. Basic meteorological parameters (temperature, pressure, relative humidity with respect to ice, wind speed and precipitation) measured by the AWS and the precipitation radar. Shown here are the mean, standard deviation, and minimum and maximum values based on hourly mean values, in the case of precipitation daily mean values, for the three measurement periods (each from 1 December to 20 February).

\begin{tabular}{lrrr}
\hline Variable & $\begin{array}{c}\text { 2013-2014 } \\
\text { Mean (SD), min, max }\end{array}$ & $\begin{array}{r}\text { 2014-2015 } \\
\text { Mean (SD), min, max }\end{array}$ & $\begin{array}{r}\text { 2015-2016 } \\
\text { Mean (SD), min, max }\end{array}$ \\
\hline Air temperature $\left({ }^{\circ} \mathrm{C}\right)$ & $-9.4(3.1),-19.3,0.5$ & $-9.7(2.7),-17.6,-0.5$ & $-10.1(2.7),-20.5,2.3$ \\
Pressure $(\mathrm{hPa})$ & $833.4(5), 817.3,844.3$ & $829.7(4.7), 812,843.5$ & $828.6(6.6), 807,845.3$ \\
RH $(\%)$ & $61.9(18.6), 13.1,100$ & $58.9(17.2), 14,100$ & $64.3(18.2), 14.7,100$ \\
Wind speed $\left(\mathrm{m} \mathrm{s}^{-1}\right)$ & $4.35(2.87), 0.13,16.21$ & $4.26(2.89), 0.03,22.59$ & $4.21(2.99), 0,16.6$ \\
Precipitation $\left(\mathrm{mm} \mathrm{day}^{-1}\right)$ & $0.38(-),-, 8.6$ & $0.24(-),-, 8.3$ & $0.35(-),-, 6.9$ \\
\hline
\end{tabular}

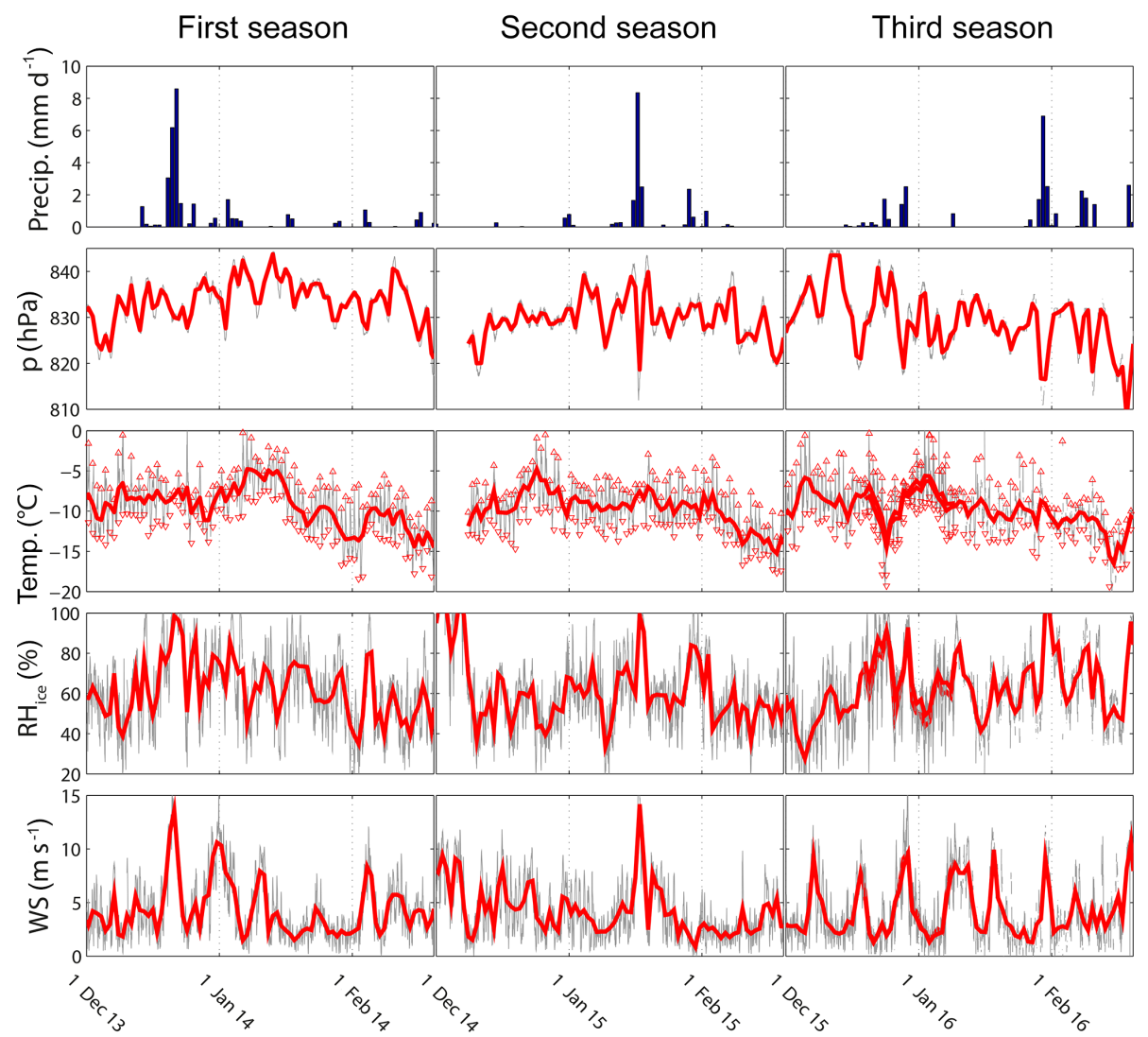

Figure 2. Time series of hourly (gray) and daily (red) mean values for temperature, pressure, relative humidity with respect to ice (RH) and wind speed (WS) measured by the AWS. Maximum and minimum temperature values are shown as triangles. The daily precipitation measured by the precipitation radar is shown as bars.

side, $0.7 \mathrm{~m}$ of a $3 / 8 \mathrm{in.}$ ( $0.19 \mathrm{in.} \mathrm{inner} \mathrm{diameter)} \mathrm{conductive}$ flexible tubing made the connection to the CPC in a smooth bend from the ceiling of the container down to the CPC. On the roof of the container, $0.15 \mathrm{~m}$ of the same flexible tubing was connected to the stainless steel tubing in order to serve as inlet without a size cut-off. With this kind of inlet, there were never issues with inlets clogged by snow during storms, which is particularly important during the uninhabited winter periods. The clogging of inlets caused by riming never happened, due to the extreme dryness at the measurement site.
The CPC was operated with a $4 \mathrm{~L}$ butanol reservoir bottle. Consumption of butanol was between 3 and $3.5 \mathrm{~L}$ for a complete year of measurements. Each austral summer the CPC was checked on leaks and the butanol was exchanged. The procedure to assure uncontaminated data is described further below.

In parallel with $N_{\mathrm{CN}}$ the particle number size distribution (PNSD) was measured by means of an LAS (TSI model 3340) in the size range from $90 \mathrm{~nm}$ to $6.8 \mu \mathrm{m}(99 \mathrm{log}$ distributed channels). The inlet set-up and tubing for the 
LAS are similar to those for the $\mathrm{CPC}$, and inside the container, the LAS was located next to the CPC. However, inside, first $0.5 \mathrm{~m}$ of a $1 / 8$ inch (inner diameter) and then $0.2 \mathrm{~m}$ of a $1 / 16$ inch (inner diameter) conductive flexible tubing connected (no bend) to the measurement chamber of the LAS. The LAS was operated with a sample flow rate of $0.07 \mathrm{~L} \mathrm{~min}^{-1}$ and a sheath flow of $0.6 \mathrm{~L} \mathrm{~min}^{-1}$. While no aerosol drying was installed in front of the LAS, ambient humidities and temperatures together with temperatures inside the container and the LAS were such that it can safely be assumed that relative humidities in the aerosol sampled for size distribution measurements were below $20 \%$. The LAS was maintained and recalibrated in spring 2015 by TSI Inc. In October 2015, before shipment to Antarctica, the LAS, which measures optical diameters, was compared to an SMPS system (differential mobility analyzer - DMA - type Hauke Medium; CPC - TSI model 3010 at the cloud laboratory of the Leibniz Institute for Tropospheric Research (TROPOS). 16 selected sizes $(80,90,100,110,120,130,140,150,175$, $200,250,300,350,400,500$ and $600 \mathrm{~nm}$ ) of ammonium sulfate particles and four sizes $(100,500,700$ and $800 \mathrm{~nm})$ of PSL $^{\mathrm{TM}}$ standard solutions were used to validate the counts of the LAS. At $500 \mathrm{~nm}$, both ammonium sulfate and PSL ${ }^{\mathrm{TM}}$ particles resulted in similar signals; however, at $100 \mathrm{~nm}$, signals for PSL ${ }^{\mathrm{TM}}$ appeared in a broad range of channels, so here only ammonium sulfate particles were used for the validation. Necessary corrections were high in the two LAS channels below $100 \mathrm{~nm}$ (around $+70 \%$ ), $+10 \%$ in the two channels around $100 \mathrm{~nm}$ and low in the other size ranges up to $800 \mathrm{~nm}$ (between $1 \%$ and $5 \%$, negative and positive corrections). These corrections were applied to the LAS data set used for this study. In this study, we continuously use hourly averaged $N_{\mathrm{CN}}$ values and PNSDs.

The number concentration of cloud condensation nuclei $\left(N_{\mathrm{CCN}}\right)$ was measured using a CCNC (Droplet Measurement Technologies - DMT, Boulder, USA). The CCNC is a continuous-flow thermal-gradient diffusion chamber which is described in detail by Roberts and Nenes (2005). The inlet tubing for the CCNC consisted of a $2.2 \mathrm{~m}$ long vertical conductive flexible tubing (similar to the one used for the CPC and LAS), with a smooth bend only just before the inlet of the CCNC. The inlet outside was directly next to the inlets of the CPC and LAS. The CCNC was operated as recommended by Gysel and Stratmann (2013) for polydisperse $\mathrm{CCN}$ measurements. The $\mathrm{CCNC}$ was operated at a constant total flow rate of $0.5 \mathrm{~L} \mathrm{~min}^{-1}$ and at five different SSs $(0.1 \%$, $0.2 \%, 0.3 \%, 0.5 \%$ and $0.7 \%$ ), each for $12 \mathrm{minh}^{-1}$. To ensure stable column temperatures, the first $5 \mathrm{~min}$ and the last $30 \mathrm{~s}$ at each SS setting were excluded from the data analysis. The remaining data points were averaged so that the result is one $N_{\mathrm{CCN}}$ value per SS per hour. For consistency checks between $N_{\mathrm{CN}}$ and $N_{\mathrm{CCN}}$, additional measurements at an SS of $1 \%$ were made a few times during each season. Respective values for $N_{\mathrm{CCN}} / N_{\mathrm{CN}}$ were generally between 0.8 and 0.9. As we will discuss later, the aerosol at the PE sta- tion is strongly dominated by particles in the nucleation- and Aitken mode size range, and at the SS of $1 \%$, not all particles have been activated (for example, activation of particles will occur down to 36 and $24 \mathrm{~nm}$ for an hygroscopicity parameter $\kappa$ of 0.3 and 1 , respectively). Hence this consistency check could not be applied here. But prior to each of the three measurement periods in Antarctica an SS calibration of the CCNC was done at the cloud laboratory of TROPOS. These calibrations were performed with size-selected ammonium sulfate particles for pressure conditions relevant to the PE station (approximately $820 \mathrm{hPa}$,) based on recommendations given by Gysel and Stratmann (2013) and Rose et al. (2008). Besides for calibration curves for the CCNC, the ratios of $N_{\mathrm{CCN}} / N_{\mathrm{CN}}$ were also derived for particles of different sizes between 120 and $200 \mathrm{~nm}$ at SS between $0.2 \%$ and $0.7 \%$. On average $N_{\mathrm{CCN}} / N_{\mathrm{CN}}$ were $1.01,0.99$ and 0.96 for the 3 different years. All values $\left(N_{\mathrm{CN}}, N_{\mathrm{CCN}}\right.$ and PNSD) are presented with respect to standard conditions, i.e., a pressure of $1013.25 \mathrm{hPa}$ and a temperature of $293.15 \mathrm{~K}$.

In addition, data from an aethalometer (Magee Sci. AE31, 7-wavelength aethalometer) were also used. The aethalometer was operated with an inlet flow of $5.5 \mathrm{~L} \mathrm{~min}^{-1}$, and, similar to the other instruments, the tubing through which it was fed was $2 \mathrm{~m}$ of flexible conductive tubing, including the inlet on the roof of the measurement container. The measurement interval was set to $60 \mathrm{~min}$. Aethalometer data were analyzed following the guidelines in WMO (2016).

The container for the aerosol measurements is located $60 \mathrm{~m}$ south of the PE main station (Fig. 1a). It was most often exposed to uncontaminated air due to the fact that the PE station is designed as a zero-emission station and that the daily activities are concentrated in the west-northwest sector while the main wind directions are from south to east (Fig. 1c). The container is well-insulated and equipped with a small heater. Heating was hardly necessary in the austral summer (due to $24 \mathrm{~h}$ sunlight). However, there is no air conditioning system due to its additional energy demand, and because during the austral winter, it would have to be remotely controlled (including remotely controlled exchanges of necessary filter systems). Therefore, in the austral summer, the temperature inside the container varied between $\approx 10$ and $40^{\circ} \mathrm{C}$. This range exceeds the recommended operating temperature ranges of the CPC and the LAS of 10 to $35^{\circ} \mathrm{C}$ and 10 to $30^{\circ} \mathrm{C}$, respectively, as well as the temperature range for which the CCNC was calibrated, which is 20 to $30^{\circ} \mathrm{C}$. Therefore, $N_{\mathrm{CN}}, N_{\mathrm{CCN}}$ and PNSDs measured during time periods in which the temperature inside the measurement container was outside of the operating temperature ranges were excluded from the analysis presented here.

Further, as mentioned in Sect. 2.1, the data were still partly influenced by emissions from the activities at the station. In order to identify hourly intervals with contamination, the following data sets were examined: (i) the minute-byminute $N_{\mathrm{CN}}$ data, (ii) simultaneously measured hourly data for the mass concentration of light-absorbing aerosol mea- 


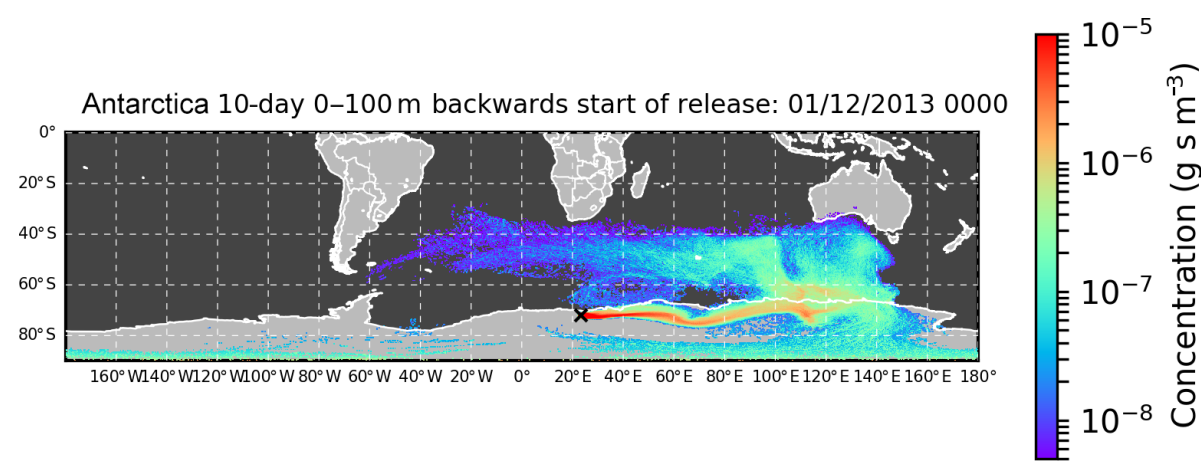

Figure 3. NAME dispersion model 10-day backwards footprint. It shows the spatial distribution of particles that were released within $3 \mathrm{~h}$ at the PE station and then tracked back in time over 10 days, based on back trajectories. The location of these particles was recorded every $15 \mathrm{~min}$ in a snapshot, and these were then summed to obtain the footprint.

sured with the aethalometer, and (iii) wind speed and wind direction measured by the AWS. As indicators for contamination, abrupt peaks, outliers, and strong variations between higher and lower minute-by-minute $N_{\mathrm{CN}}$ values and/or distinctly higher mass concentrations of light-absorbing aerosol $\left(>50 \mathrm{n} \mathrm{m}^{-3}\right.$ ) were used. Because the PE station was designed as a zero-emission station, there was no relationship between wind speed or wind direction with elevated values for $N_{\mathrm{CN}}$ or light-absorbing aerosol. However, each hourly interval with wind speed $<3 \mathrm{~m} \mathrm{~s}^{-1}$ and/or wind direction outside the sector of 20 to $225^{\circ}$ was examined again for conspicuous signals in its variation in time.

The hygroscopicity of the aerosol particles was determined by applying the $\kappa$ Köhler theory (Petters and Kreidenweis, 2007). The inferred hygroscopicity parameter $\kappa$ represents the average particle composition. To infer $\kappa$, the critical diameter $\left(d_{\text {crit }}\right)$ first needs to be determined, based on the measured $N_{\mathrm{CCN}}$ and PNSD. This is the diameter at which particles are just large enough to be activated to a droplet when exposed to a certain SS. For a pair of simultaneously measured PNSD and $N_{\mathrm{CCN}}, d_{\text {crit }}$ is obtained by calculating the cumulative particle number concentration from that PNSD, from the largest diameter on downward, and it is the diameter at which this cumulative concentration is equal to $N_{\mathrm{CCN}}$. Using the assumption that the surface tension is equal to that of pure water, $d_{\text {crit }}$ and the SS are used to derive $\kappa$ values of the Antarctic aerosol particles. This approach, however, assumes that all particles of roughly the size of $d_{\text {crit }}$ have the same chemical composition, i.e., are internally mixed. Therefore the derived $\kappa$ values will only give rough information on the chemical composition of the examined aerosol, which, however, still can be useful in interpreting the origin of the observed aerosol particles. A detailed description of this method, including the application of a Monte Carlo simulation to precisely determine uncertainties in $d_{\text {crit }}$ and $\kappa$, is presented by Herenz et al. (2018). This procedure of inferring $\kappa$ values could only be done for $N_{\mathrm{CCN}}$ measurements at an SS of $0.1 \%$, as $d_{\text {crit }}$ for larger SSs is below the lower size limit of the PNSDs of $90 \mathrm{~nm}$.

\subsection{Identification of air mass origins and potential source regions}

To analyze the influence of the air mass origin on $N_{\mathrm{CN}}$ and $N_{\mathrm{CCN}}$ measured at the PE station, we applied two different models to obtain information on the air mass history. The first one is the NAME, which was used to perform a simple residence time analysis (Fleming et al., 2012). The second one is the potential source contribution function (PSCF), a more advanced type of residence time analysis that results in a probability field which represents the probability of a specific location to contribute to high measured receptor concentrations (Fleming et al., 2012). As will be described in more detail below, the two models are based on different sets of back trajectories, i.e., they were used in the framework in which they have been tested and applied in the past.

\subsubsection{The NAME dispersion model}

The NAME atmospheric dispersion model (Jones et al., 2007) is a Lagrangian particle-trajectory model, that is operated by the UK Meteorological Office. For this study 10000 abstract particles per hour were released at $10 \mathrm{~m}$ above the location of the PE station. On the basis of the Meteorological Office Unified Model (UM) meteorological field data, 10-day back trajectories for these particles were calculated. Summing up the concentration of these particles at backwards time steps of 15 min (in total, 960 time steps) results in a footprint that shows the history of the air masses during the last 10 days. For this procedure, only particles that are located within the surface layer (i.e., $0-100 \mathrm{~m}$ above ground) are taken into account. An example footprint of the first of December 2013 (midnight) is shown in Fig. 3. Footprints were derived every $3 \mathrm{~h}$, resulting in a total number of 2019 NAME footprints used in this study. To further analyze the impact of different surface properties on the mea- 


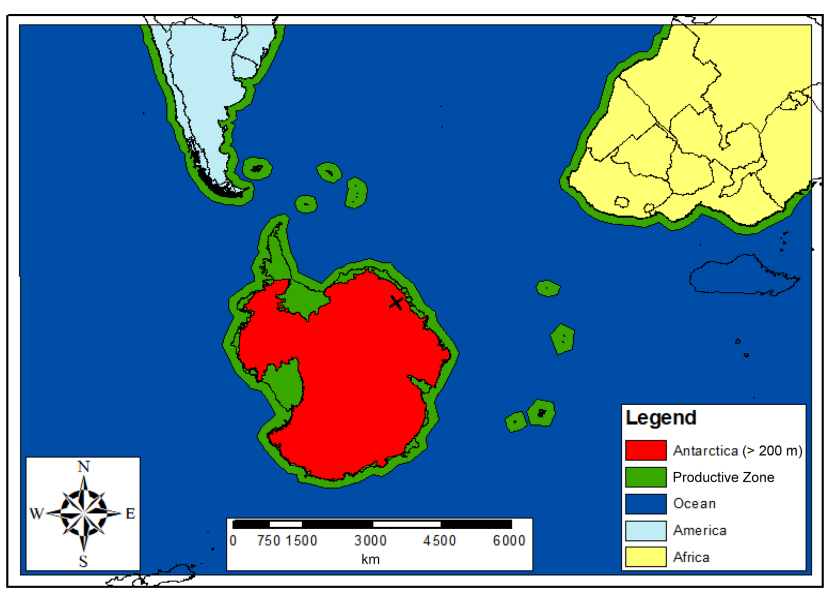

Figure 4. Five different regions (Southern Ocean, Antarctic inland plateau, South America, Africa and Productive Zone) that are used to track the percentage of residence time in each region before arriving at PE from the NAME footprints.

sured aerosol particle properties, the area around Antarctica was divided into the following five regions (see also Fig. 4): the Antarctic escarpment zone and inland plateau (continental area at or above $200 \mathrm{~m}$ a.s.l.), the Southern Ocean, South America, Africa, and the Productive Zone.

In marine regions at lower latitudes, sea spray particles generally contribute only small fractions to total particle and CCN number concentrations (Wex et al., 2016; Quinn et al., 2017). However, at latitudes above $40^{\circ}$ (both north and south), this fraction increases, and, due to prevailing high wind speeds, the Southern Ocean may contribute sea spray particles (in a mode with sizes from roughly $100 \mathrm{~nm}$ well up into the supermicron size range) which may make up $20 \%$ to $30 \%$ of all particles, at least above the ocean (Quinn et al., 2017). But the Southern Ocean also is a source for precursor gases for NPF such as DMS and ammonia (Schmale et al., 2013). These precursors may originate in phytoplankton blooms correlated to increased chlorophyll concentrations and have been described as influencing $\mathrm{CCN}$ over the Southern Ocean (Vallina et al., 2006; Meskhidze and Nenes, 2006). The Productive Zone includes the following regions that are known to have the potential to emit either primary particles (i.e., particles from sea spray in this case) or precursors for secondarily formed particles (i.e., for NPF):

- The Antarctic continental area below 200 ma.s.l. and eight islands in the Southern Ocean (South Georgia, South Sandwich, Falkland, South Orkney, Prince Edward, Crozet, Kerguelen, Heard and McDonald). These regions are included because they are habitats for numerous different types of penguins and birds. Bird guano (Schmale et al., 2013) or penguin guano (Legrand et al., 1998) acts as a source of ammonia and may contribute to the formation of new particles in coastal Antarctic areas. Also, cyanobacteria from freshwater melt ponds have been described to contribute precursor gases to NPF and particle growth (Kyrö et al., 2013).

- The permanently and seasonally covered sea ice areas. These are known to have the potential to act as source of the organic nitrogen that contributes to secondarily formed aerosol particles (Dall'Osto et al., 2017) or to emit primary sea salt particles (Huang and Jaeglé, 2017; Yang et al., 2008; Wagenbach et al., 1998).

- The marine area up to $200 \mathrm{~km}$ from the coasts of the islands and continents (for Antarctic, continent plus ice shelves). Sea spray production may occur in this region (Quinn et al., 2017). Also, these areas are included due to an enhanced chlorophyll concentration in the coastal areas of the Southern Ocean. As previously mentioned, chlorophyll can be used as a proxy for DMS (Vallina et al., 2006), which, in turn, plays a role in NPF (Liss and Lovelock, 2008).

The proportional residence time that the air masses spent over the five different regions during the last 10 days prior to arrival at the measurement station was determined in order to assess the extent to which these regions influence the aerosol particle and $\mathrm{CCN}$ properties. This type of a residence time analysis was already used by O'Shea et al. (2017) for an Antarctic site. The comparably coarse division into the different regions used in this study was thought to yield a general idea on the possible origin of particles or particle precursors. A more detailed investigation of, for example, the variability of the ice cover or the existence of phytoplankton blooms in the examined regions is beyond the scope of our study.

\subsubsection{Potential source contribution function}

The PSCF is a receptor modeling method that was originally developed by Ashbaugh et al. (1985) and was applied in a number of high latitude studies previously, e.g., in Dall'Osto et al. (2017) for the Antarctic and in Yli-Tuomi et al. (2003) for the Arctic. The PSCF model is based on air mass back trajectories, and it is commonly used to identify regions that have the potential to contribute to high values of measured concentrations at a receptor site. In this study we apply the PSCF to $N_{\mathrm{CN}}$ and $N_{\mathrm{CCN}}$.

The NOAA HYSPLIT trajectory model (Stein et al., 2015) was used to calculate hourly resolved 10-day back trajectories based on $1^{\circ} \times 1^{\circ}$ GDAS (Global Data Assimilation System) meteorological data. To account for uncertainties in back trajectory analysis, for every hour, a set of 15 back trajectories was calculated, which is composed of five different plane locations (one exactly at the measurement station and four in close proximity to it) at three altitudes (100, 200 and $300 \mathrm{~m}$ above the surface level). In total, this results in a set of 88152 back trajectories that were used for the PSCF analysis (note that a few trajectories were excluded from the analysis, 
as they could not be properly calculated due to problems in the input data). Each back trajectory consists of trajectory points, which represent the central geographical position of the air parcel at a particular time. To calculate the PSCF the whole region that is covered by these trajectory points is divided into an array of $5^{\circ} \times 5^{\circ}$ grid cells $(i, j)$. The assumption is that aerosol particles that are emitted in such a cell are incorporated into the air parcel and transported to the receptor site. The PSCF can be calculated as follows:

$\mathrm{PSCF}_{i, j}=\frac{m_{i, j}}{n_{i, j}}$

where $n_{i, j}$ is the total number of trajectory points that fall into a cell, and $m_{i, j}$ is the number of trajectory points that fall into that cell and fulfill a given criterion, where this criterion typically is the exceedance of a certain threshold. In this study we used the $75 \%$ percentile of either $N_{\mathrm{CN}}$ or $N_{\mathrm{CCN}}$ as that threshold. According to Hopke (2016),

Cells containing emission sources would be identified with conditional probabilities close to 1 if trajectories that have crossed the cells effectively transport the emitted contaminant to the receptor site. The PSCF model thus provides a means to map the source potentials of geographical areas. It does not apportion the contribution of the identified source area to the measured receptor data.

As it is probable that small values of $n_{i, j}$ would lead to uncertain and high PSCF values, it is necessary to apply a weighting function. For this study a discrete weighting function based on $\log (n+1)$, which is a measure of the backtrajectory density, was applied (Waked et al., 2014).

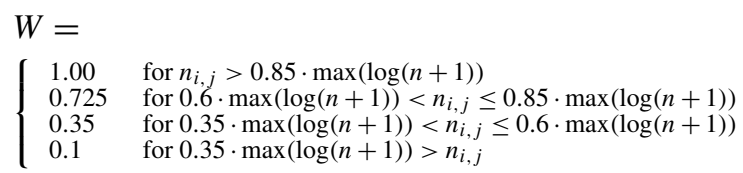

The measured concentration of total particles and $\mathrm{CCN}$ is also affected by losses that occur along the path of the air parcel between the source and the receptor site. As precipitation, which is known to be one of the major sinks for aerosol particles, particularly for $\mathrm{CCN}$, is an output parameter of the calculated NOAA HYSPLIT back trajectories, it can be taken into account. Hence, we run the PSCF model with a precipitation filter. As soon as a trajectory point showed a precipitation of $0.1 \mathrm{~mm} \mathrm{~h}^{-1}$ and the total precipitation (sum of precipitation of 240 trajectory points) of the back trajectory exceeded a value of $5 \mathrm{~mm} / 240 \mathrm{~h}$, back trajectories were cut off and not considered for the PSCF analysis. The second criterion was added, as it seemed to be unreasonable to discard a trajectory only because of showing a low precipitation of some $\mathrm{mm} \mathrm{h}^{-1}$ at some trajectory points. Since the precipitation filter criteria described here were particularly contrived for our study, we used the weighting function given in Waked et al. (2014), as already stated above.

\section{Results and discussion}

\subsection{Total particle and $\mathrm{CCN}$ number concentrations and regional analysis of the NAME model footprints}

This section presents the measured $N_{\mathrm{CN}}, N_{\mathrm{CCN}}$ and PNSDs as well as the proportional residence time of the air masses over the regions introduced in Sect. 2.3.1. Time series are given for the three austral summer seasons of 2013-2014, 2014-2015 and 2015-2016 in Figs. 6-8, respectively.

Measurements of $N_{\mathrm{CN}}$ were performed throughout the whole year between 2012 and 2016, i.e., these measurements were done during more extended periods of time than measurements of $N_{\mathrm{CCN}}$. Figure 5 shows a clear seasonal cycle with the lowest monthly median values during the austral winter and a maximum during the late austral summer. The monthly $10 \%$ and $90 \%$ percentiles also indicate the highest variability of $N_{\mathrm{CN}}$ during February. Several studies at different Antarctic sites found that the physical and chemical aerosol particle properties are subject to a similar seasonality e.g., Hara et al. (2011), Weller et al. (2011), Virkkula et al. (2009) and Kim et al. (2017). Just like $N_{\mathrm{CN}}, N_{\mathrm{CCN}}$ also follows a seasonal cycle with a minimum in the austral winter and a maximum in the austral summer (Kim et al., 2017). Hence, our measurements during the austral summer capture the season in which the aerosol production in Antarctica and the surrounding source regions is most active.

We found $N_{\mathrm{CN}}$ (black dots in panel c in Figs. 6-8) to cover a range between 40 and $6700 \mathrm{~cm}^{-3}$ (on the base of hourly averaged values), with a median value of $333 \mathrm{~cm}^{-3}$. Our measured $N_{\mathrm{CCN}}$ (bluish dots in panel c in Figs. 6-8) cover a range between less than $10 \mathrm{~cm}^{-3}$ at $\mathrm{SS}=0.1 \%$ and $1300 \mathrm{~cm}^{-3}$ for the highest SS of $0.7 \%$. The integration of the PNSD over the whole size range $\left(N_{\mathrm{CN}>90 \mathrm{~nm}}\right.$, red dots in panel c in Figs. 6-8) shows the aerosol particle number concentration in the size range between $90 \mathrm{~nm}$ and $6.8 \mu \mathrm{m}$. $N_{\mathrm{CN}>90 \mathrm{~nm}}$ has a median value of $20 \mathrm{~cm}^{-3}$. The median, $10 \%$ and $90 \%$ percentile

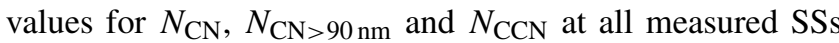
are summarized in the first column of Table 2. O'Shea et al. (2017) and Kim et al. (2017) both also report $N_{\mathrm{CCN}}$ determined during the austral summer, however, at coastal Antarctic locations. O'Shea et al. (2017) show $N_{\mathrm{CCN}}$ of approximately 20,120 and $250 \mathrm{~cm}^{-3}$, on average, at an SS of $0.08 \%$, $0.2 \%$ and $0.53 \%$, respectively, and just under $200 \mathrm{~cm}^{-3}$ at an SS of $0.4 \%$ are given in Kim et al. (2017). These $N_{\mathrm{CCN}}$ are roughly $50 \%$ higher than those determined herein, across all SSs. This might be explained by our measurement site's longer distance to the Southern Ocean. As we will show below, air masses often traveled over Antarctica for extended times before reaching our measurement station, which might be connected to an increased washout of particles by precipitation along the way.

The third column of Table 2 shows the ratio of $N_{\mathrm{CN}>90 \mathrm{~nm}}$ and $N_{\mathrm{CCN}}$ at different $\mathrm{SSs}$ to $N_{\mathrm{CN}}$ (based on the median values of the first column in Table 2). The values of 
Table 2. Overview showing $N_{\mathrm{CN}}, N_{\mathrm{CN}>90 \mathrm{~nm}}$ and $N_{\mathrm{CCN}}$ at different SSs, given as median (and $10 \%$ and $90 \%$ percentiles in brackets) in column 1 for all data and in column 2 for CEs (continental events, based on the regional analysis of the NAME model output). Column 3 shows the ratio of $N_{\mathrm{CN}>90 \mathrm{~nm}}$ and $N_{\mathrm{CCN}}$ to $N_{\mathrm{CN}}$ (based on the median values of column 1).

\begin{tabular}{lrrr}
\hline Parameter & $\begin{array}{r}\text { Median concentration } \\
(10 \%, 90 \% \text { percentile }) \\
\left(\mathrm{cm}^{-3}\right)\end{array}$ & $\begin{array}{r}\text { Median concentration } \\
\text { during CEs }(10 \%, 90 \% \\
\text { percentile })\left(\mathrm{cm}^{-3}\right)\end{array}$ & $\begin{array}{r}N_{\mathrm{CN}} \text { (LAS) } / \\
N_{\mathrm{CN}}(\mathrm{CPC}) \\
\text { or } N_{\mathrm{CCN}} / \\
N_{\mathrm{CN}}(\mathrm{CPC})\end{array}$ \\
\hline$N_{\mathrm{CN}}(\mathrm{CPC})$ & $333(206,893)$ & $292(205,474)$ & - \\
$N_{\mathrm{CN}>90 \mathrm{~nm}}(\mathrm{LAS})$ & $20(14,29)$ & $20(14,29)$ & 0.06 \\
$N_{\mathrm{CCN}, 0.1 \%}$ & $14(10,23)$ & $14(10,21)$ & 0.04 \\
$N_{\mathrm{CCN}, 0.2 \%}$ & $81(56,110)$ & $79(58,105)$ & 0.24 \\
$N_{\mathrm{CCN}, 0.3 \%}$ & $121(90,168)$ & $120(95,161)$ & 0.36 \\
$N_{\mathrm{CCN}, 0.5 \%}$ & $177(125,260)$ & $177(133,232)$ & 0.53 \\
$N_{\mathrm{CCN}, 0.7 \%}$ & $212(138,326)$ & $210(150,292)$ & 0.64 \\
\hline
\end{tabular}

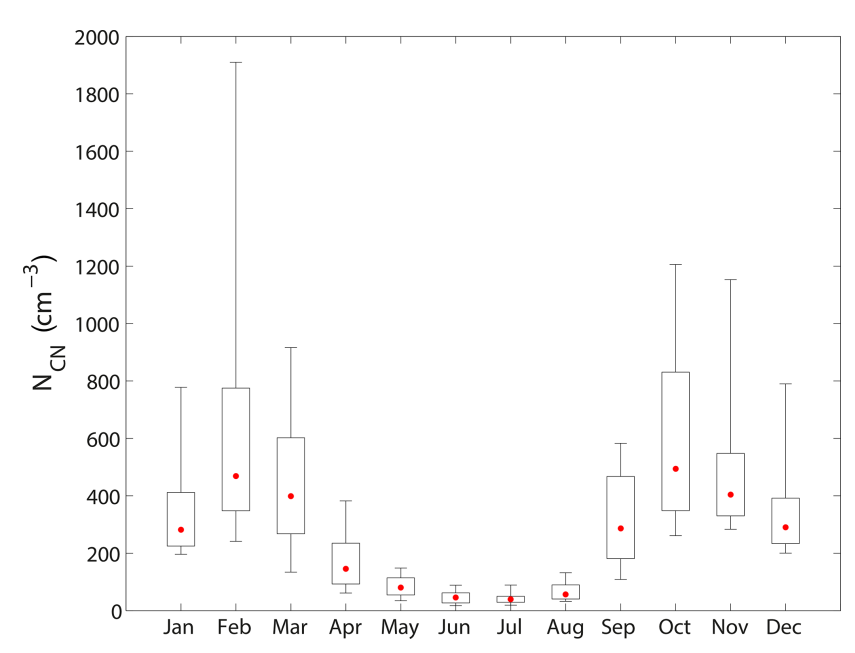

Figure 5. Box plot of monthly median values (red dots), interquartile range (black box), and $10 \%$ and $90 \%$ percentile (black bars) of $N_{\mathrm{CN}}$ measured at the PE station between 2012 and 2016.

$N_{\mathrm{CN}>90 \mathrm{~nm}} / N_{\mathrm{CN}}$ and $N_{\mathrm{CCN}, 0.7 \%} / N_{\mathrm{CN}}$ are 0.06 and 0.64 , respectively. This indicates that the aerosol particles feature an Aitken mode dominance, as $94 \%$ of the aerosol particles are smaller than $90 \mathrm{~nm}$. Assuming a hygroscopicity parameter $\kappa$ of 0.8 for the coastal area of East Antarctica, taken from Pringle et al. (2010), the critical diameter $d_{\text {crit }}$ for $\mathrm{SS}=0.7 \%$ was determined by means of the $\kappa$ Köhler theory to be $\approx 35 \mathrm{~nm}$. On the basis of this assumption $36 \%$ the aerosol particles are smaller than roughly $35 \mathrm{~nm}$. That is indicative of a high amount of newly formed aerosol particles, which form from precursor gases emitted from the Southern Ocean and the Productive Zone, such as ammonia and DMS (see Sect. 2.3.1). The corresponding NPF events occurring during the passage of the air masses to the measurement site likely take place in the free troposphere (Fiebig et al., 2014; Quinn et al., 2017). Primary emitted natural aerosol particles that are known to occur in Antarctica from, for exam- ple, mineral dust (Wegner et al., 2015) or sea salt (Huang and Jaeglé, 2017; Yang et al., 2008; Wagenbach et al., 1998) are known to clearly exceed this size (Lamb and Verlinde, 2011). Unfortunately, we cannot examine the Aitken mode particles in much more detail, as our PNSD data are in the size range $90-6.8 \mu \mathrm{m}$ and hence only show the accumulationand coarse-mode particles. However, several other studies at coastal Antarctic sites report PNSD measurements that show pronounced and dominant Aitken modes during the austral summer (e.g., Asmi et al., 2010; O'Shea et al., 2017; Kim et al., 2017).

Panel $d$ in Figs. 6-8 shows the regional analysis of the NAME footprints, as described in Sect. 2.3.1. It can give insight into the influence of the air mass origin on $N_{\mathrm{CN}}$ and $N_{\mathrm{CCN}}$. The regional analysis shows that during the 10 days prior to the measurements, air masses only have been influenced by the Antarctic continent, the Southern Ocean and the Productive Zone region but not by South America or Africa. Thus, we can be confident that we mainly measured pristine air masses and aerosol particles of a natural origin without much anthropogenic influence.

The contributions from Antarctica, the Southern Ocean and the Productive Zone region show a large variability. During $61 \%$ of the measurement times, the air masses spent $\geq$ $90 \%$ of the 10 days prior to their arrival at the measurement site over the continental region. These times are called continental events (CEs) from now on. During CEs, we record only a low variability in the measured $N_{\mathrm{CN}}$ and $N_{\mathrm{CCN}}$. To illustrate this, the different panels of Fig. 9 show scatter plots and box and whisker plots, displaying $N_{\mathrm{CN}}$ and $N_{\mathrm{CCN}}$ (the latter at the two exemplary SSs of $0.3 \%$ and $0.7 \%$ ) versus the fraction of time that the respective air masses spent over the Antarctic region (continental fraction). All data from the three seasons are included. It can clearly be seen in Fig. $9 \mathrm{a}$ and $\mathrm{b}$ that $N_{\mathrm{CN}}$ scatters the least and reaches the lowest median value during CEs (note: only few data points exist for the low continental fractions of $<30 \%$, making their median and percentiles statistically unreliable). During 


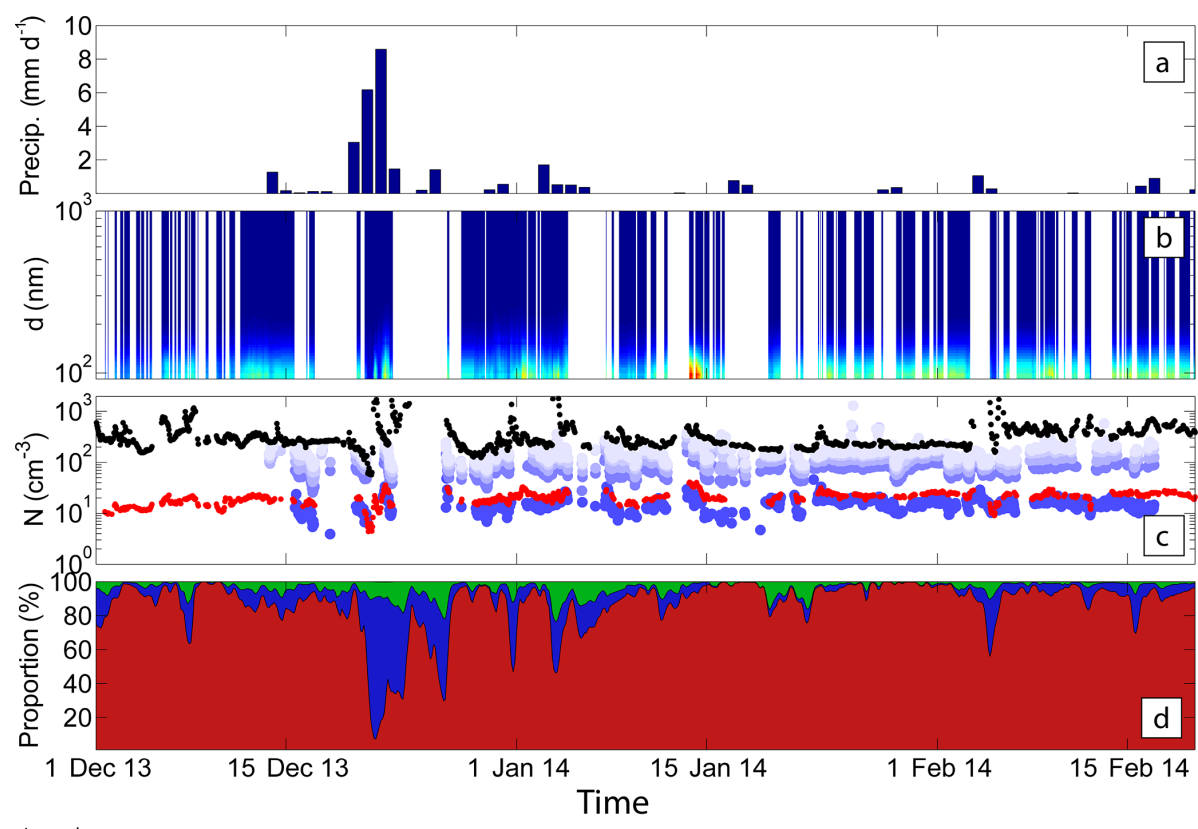

\begin{tabular}{|llllll|}
\hline 300 & $-\mathrm{N}_{\mathrm{CN}}(\mathrm{CPC} 3776)$ & $-\mathrm{N}_{\mathrm{CCN}} @ \mathrm{SS}=0.1 \%$ & $\mathrm{~N}_{\mathrm{CCN}} @ \mathrm{SS}=0.3 \%$ & Antarctica \\
$\frac{\mathrm{dN}}{\mathrm{dlogdp}}{ }^{\left(\mathrm{cm}^{-3}\right)}$ & $-\mathrm{N}_{\mathrm{CN}}(\mathrm{LAS})$ & $-\mathrm{N}_{\mathrm{CCN}} @ \mathrm{SS}=0.2 \%$ & $\mathrm{~N}_{\mathrm{CCN}} @ \mathrm{SS}=0.5 \%$ & Productive zone \\
0 & & & $\mathrm{~N}_{\mathrm{CCN}} @ \mathrm{SS}=0.7 \%$ & Ocean \\
\hline
\end{tabular}

Figure 6. Time series of the first season (December 2013 to February 2014) of (a) daily precipitation shown as bars (same data as in Fig. 2); (b) PNSDs, depicted between $90 \mathrm{~nm}$ and $1 \mu \mathrm{m}$; (c) $N_{\mathrm{CN}}$ measured by the CPC in black, $N_{\mathrm{CN}}$ measured by the LAS (integrated concentration between $90 \mathrm{~nm}$ and $6.8 \mu \mathrm{m}$ ) in red, and $N_{\mathrm{CCN}}$ measured by the CCNC at SS between $0.1 \%$ and $0.7 \%$ in different blue colors; (d) proportion of residence of the air masses over the Antarctic continent (red area), the Productive Zone (green area) and the Southern Ocean (blue area) areas during the past 10 days (based on the NAME model footprints).

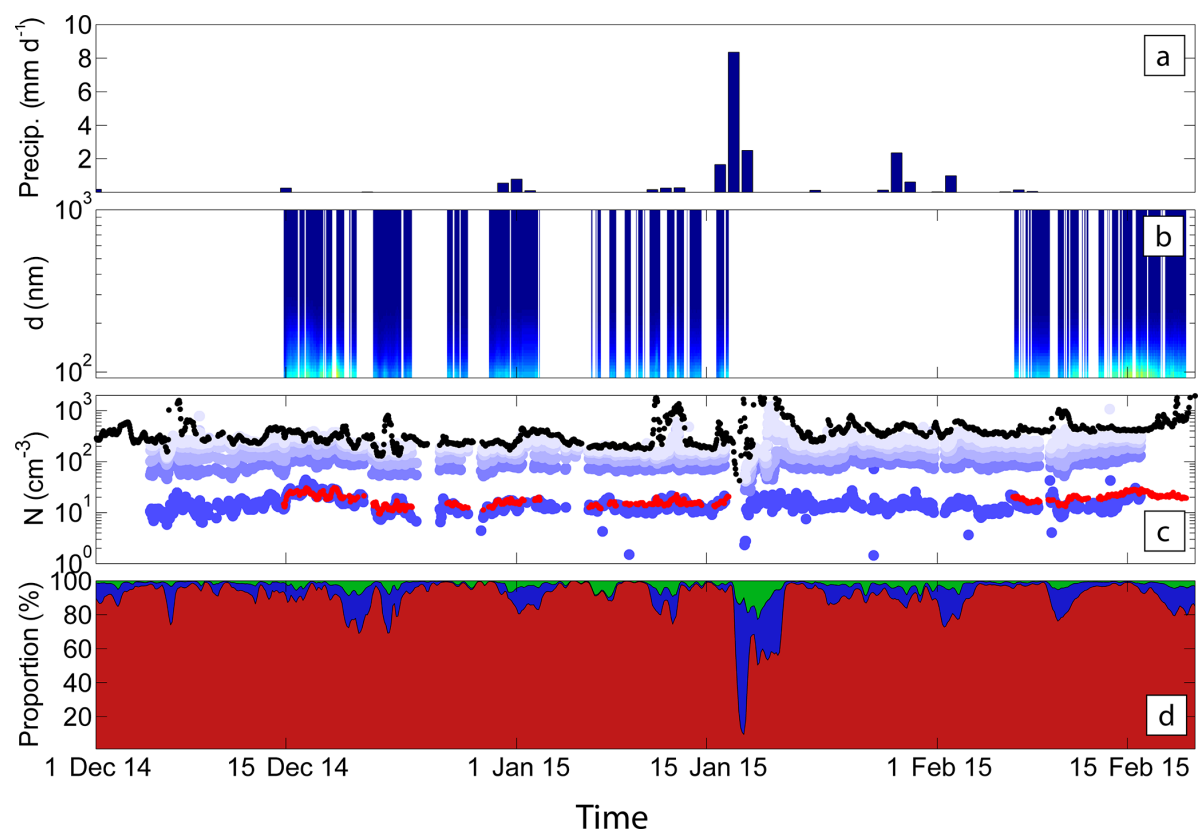

Figure 7. Time series of the second season (December 2014 to February 2015). For further details see caption of Fig. 6. 


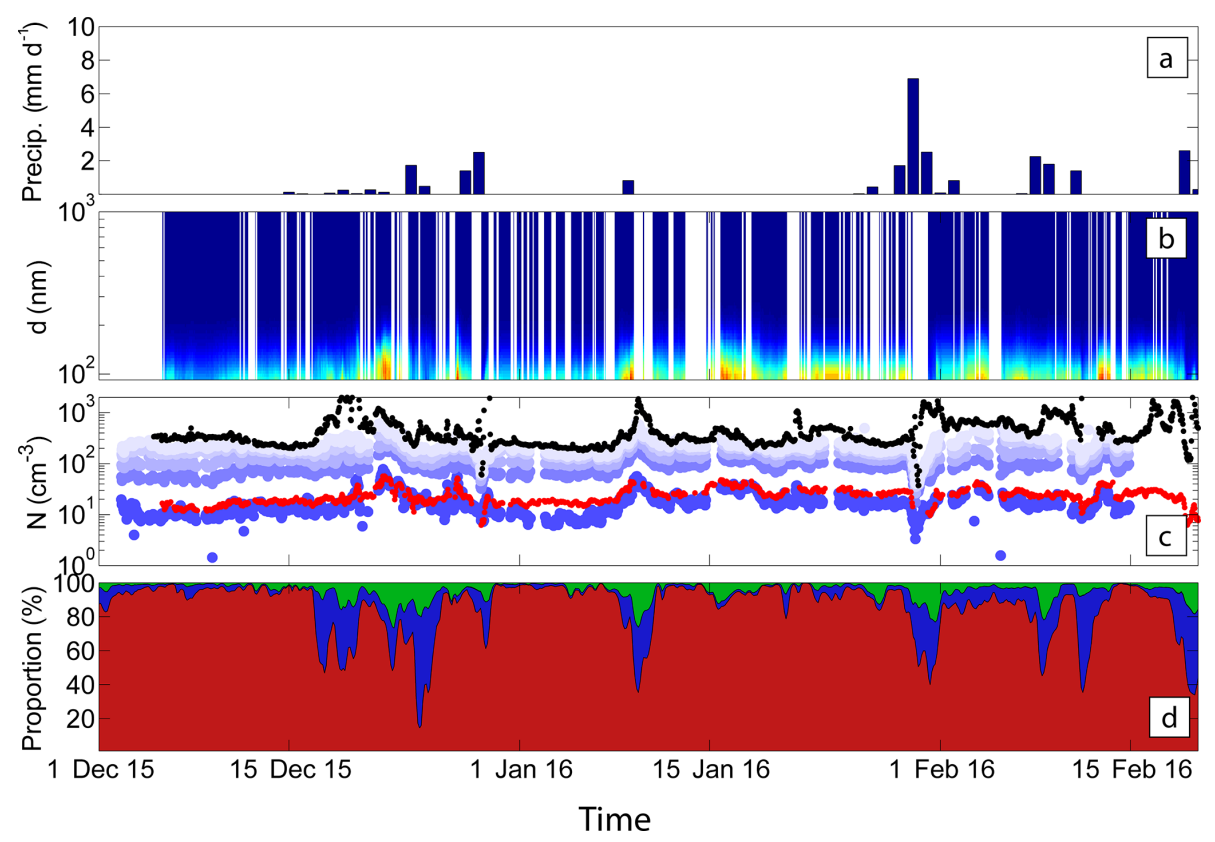

Figure 8. Time series of the third season (December 2015 to February 2016). For further details see caption of Fig. 6.

CEs, $N_{\mathrm{CN}}$ rarely exceeds $475 \mathrm{~cm}^{-3}$, with maximum values of $990 \mathrm{~cm}^{-3}$, while $90 \%$ of $N_{\mathrm{CN}}$ covers a range from 170 to $475 \mathrm{~cm}^{-3}$. The same tendencies described here for $N_{\mathrm{CN}}$ are observed for $N_{\mathrm{CCN}}$. The concentration ranges during CEs for $N_{\mathrm{CN}}, N_{\mathrm{CN}>90 \mathrm{~nm}}$ and $N_{\mathrm{CCN}}$ at all SSs are shown in the second column of Table 2 . These concentration ranges can be assumed to be pristine Antarctic continental background concentrations during the austral summer.

During $39 \%$ of the time, the proportion of the Productive Zone plus the Southern Ocean region was larger than $10 \%$; from now on we call these times marine events (MEs). During MEs we record an enhanced variability in $N_{\mathrm{CN}}$ and $N_{\mathrm{CCN}}$. The precipitation, depicted in panel a of Figs. 6-8, also shows a connection to MEs. Especially strong precipitation events only occur during the MEs that are most intense, affecting PE, e.g., on 21 December 2013, 18 January 2015 and 30 January 2016, in line with the findings of Gorodetskaya et al. (2014) and Souverijns et al. (2018). These precipitation events significantly decrease $N_{\mathrm{CN}}$ and $N_{\mathrm{CCN}}$ on a time scale of some hours to 1 day, due to scavenging and wet deposition. The minimum values that we report for $N_{\mathrm{CN}}$ and $N_{\mathrm{CCN}}$ were measured during these strong precipitation events. As the Antarctic region does not act as a significant source of water vapor (see katabatic meteorological regime in Sect. 2.1), it is self-explanatory that strong precipitation events only occur during MEs. But, also, the highest values for $N_{\mathrm{CN}}$ and $N_{\mathrm{CCN}}$ are only observed during MEs. The Productive Zone and the Southern Ocean region potentially represent source regions for primary and secondary formed aerosol particles. As already mentioned in Sect. 2.3.1 the region of the Productive Zone can contribute to the Antarctic aerosol particle loading due to sea bird and penguin guano and microbiota occurring in open meltwater ponds and related to sea ice, all connected to the release of ammonia that potentially contributes to the formation of new particles (Legrand et al., 1998; Kyrö et al., 2013; Schmale et al., 2013; Dall'Osto et al., 2017). Maybe more importantly, the Productive Zone and the Southern Ocean region also emit DMS, whose oxidation products, sulfuric and methanesulfonic acid, similarly contribute to NPF and have the ability to form aerosol particles that grow to $\mathrm{CCN}$ sizes (Liss and Lovelock, 2008). Also, these regions have the potential to contribute to the aerosol particle loading by primary emissions of sea salt particles due to blowing snow on sea ice surfaces (Huang and Jaeglé, 2017; Yang et al., 2008; Wagenbach et al., 1998) or bubble bursting from wave activity (Lamb and Verlinde, 2011).

The time series of $N_{\mathrm{CN}}$ in Figs. 6-8 often show a spontaneous increase during MEs of several thousand particles per centimeter cubed. Figure 10 exemplarily shows such an event, which took place on 6 December 2014. Between 07:00 and 10:00 GMT $N_{\mathrm{CN}}$ increased from $\approx 200$ to $\approx$ $6000 \mathrm{~cm}^{3}$. This was accompanied by an increase of $N_{\mathrm{CCN}}$. In total we detected 12 comparable events with an increase of $N_{\mathrm{CN}}$ up to several thousand particles per centimeter cubed that all took place in a time frame between several hours and $\approx 1$ day. In the vast majority of cases, these events of increased $N_{\mathrm{CN}}$ were accompanied by an increase of $N_{\mathrm{CCN}}$ by a factor of, at least, roughly 2 at all SSs. Other studies at Antarctic sites report events of NPF during the austral summer, e.g., Asmi et al. (2010) and Weller et al. (2015) at the Finnish research station Aboa and the German Neumayer sta- 


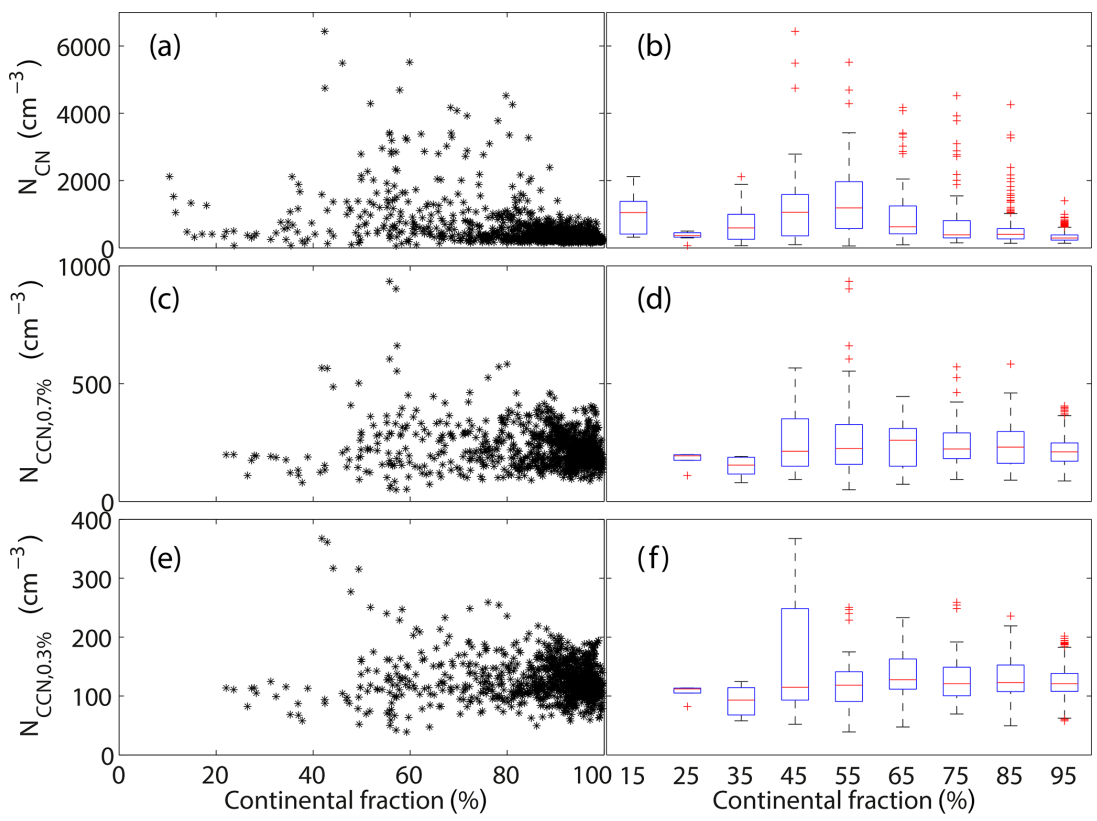

Figure 9. Connection between $N_{\mathrm{CN}}$ and $N_{\mathrm{CCN}}$ (at SSs of $0.3 \%$ and $0.7 \%$ ) and the occurrence of continental air masses. While (a, c,e) show the data separately, (b, d, f) give a box and whisker plot with median values and the interquartile range (blue boxes).

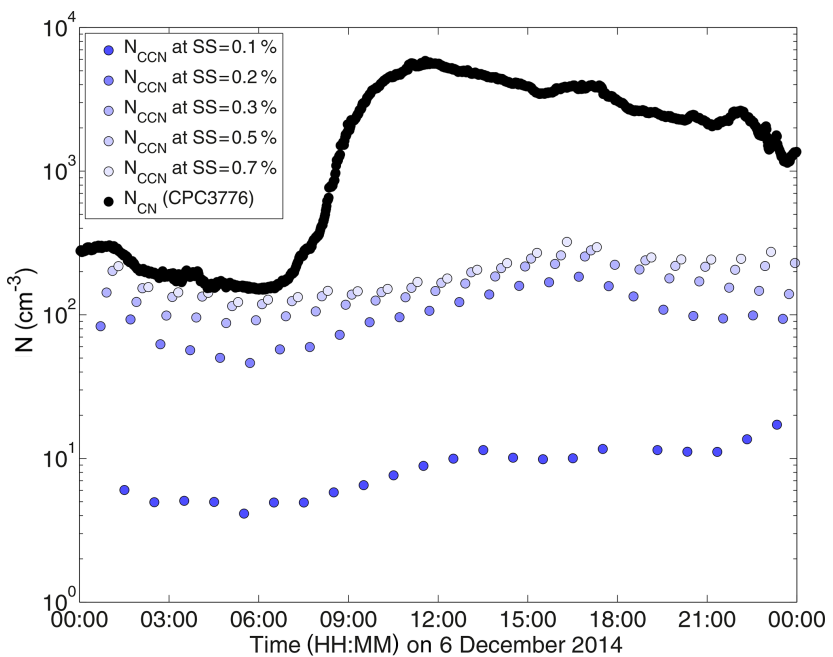

Figure 10. $N_{\mathrm{CN}}$ and $N_{\mathrm{CCN}}$ during an event of NPF at the PE station.

tion, respectively, which are both coastal sites. Järvinen et al. (2013) even reported the observation of NPF at Dome C, a site in central Antarctica. Median growth rates of particles from NPF were $\approx 2.5 \mathrm{~nm} \mathrm{~h}^{-1}$ at Dome $\mathrm{C}$ throughout the year and 3.4 and $0.6 \mathrm{~nm} \mathrm{~h}^{-1}$ for particles up to and above $25 \mathrm{~nm}$, respectively, in the austral summer. At Aboa, variable growth rates were reported, ranging from 0.8 to $2.5 \mathrm{~nm} \mathrm{~h}^{-1}$, reported in Asmi et al. (2010), and from 1.8 to $8.8 \mathrm{~nm} \mathrm{~h}^{-1}$, derived in Kyrö et al. (2013), while growth rates were only $\approx 1 \mathrm{~nm} \mathrm{~h}^{-1}$ for the costal site of Neumayer (Weller et al., 2015). While it was also described that particles rarely grow to sizes larger than $\approx 25 \mathrm{~nm}$ at Neumayer (Weller et al., 2015), i.e., that they do not reach sizes at which they can readily act as $\mathrm{CCN}$, growth of newly formed particles into the $\mathrm{CCN}$ size range was reported for Aboa, likely due to precursor emissions from local meltwater ponds (Kyrö et al., 2013) or due to precursor gases advected to the site with marine and coastal air masses (Koponen et al., 2003). The surprisingly high growth rates observed at Dome $\mathrm{C}$ may be related to air masses that had picked up precursor gases for the formation of particulate matter over the Southern Ocean or the region defined as the Productive Zone herein and those were subsequently transported in the free troposphere followed by descent over Antarctica (Fiebig et al., 2014). This is likely a process occurring widely in Antarctica, for which not the availability of precursor gases but rather the photooxidative capacity regulates the connected NPF and particulate growth (Fiebig et al., 2014). Tropospheric NPF with subsequent growth therefore also likely explains the observations at the PE station described above.

Our measured PNSDs do not cover the size range of the nucleation and Aitken mode, however, in combination with measurements of $N_{\mathrm{CN}}$ and $N_{\mathrm{CCN}}$, we can state that particles originating from NPF events and subsequent growth were observed during our measurements. Our measurements at the PE station show that these freshly formed aerosol particles seem to reach size ranges relevant for $\mathrm{CCN}$ activation and are thus climatically relevant. 

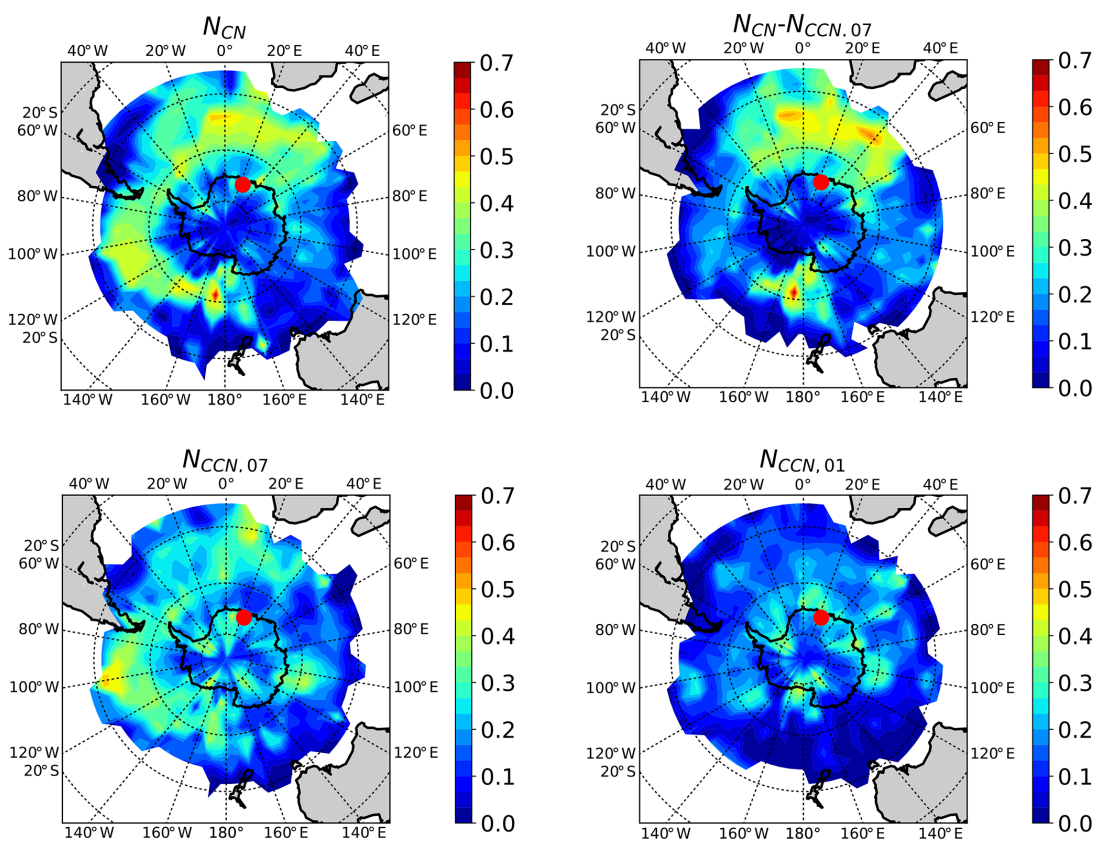

Figure 11. PSCF results that are plotted over a map of Antarctica for $N_{\mathrm{CN}}, N_{\mathrm{CN}}-N_{\mathrm{CCN}, 0.7 \%}, N_{\mathrm{CCN}, 0.7 \%}$ and $N_{\mathrm{CCN}, 0.1 \%}$. The color bar indicates the value of the PSCF.

\subsection{Air mass origins and potential source regions}

Figure 11 shows the spatial distribution of the PSCF calcu-

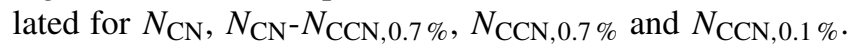
These four parameters represent concentrations of all particles (with a lower size cut at $3 \mathrm{~nm}$ ), particles in the size range up to $\approx 35 \mathrm{~nm}$, particles with sizes above $\approx 35 \mathrm{~nm}$ and the largest particles above $\approx 110 \mathrm{~nm}$, respectively. (The parameter $N_{\mathrm{CN}}-N_{\mathrm{CCN}, 0.7 \%}$ denotes concentrations of all particles minus those that are CCN at an SS of $0.7 \%$.) The analysis was done using the data of all three austral summer periods, which is a data set of approximately 230 days and a corresponding set of 88152 back trajectories. The $75 \%$ percentile values of $N_{\mathrm{CN}}, N_{\mathrm{CN}}-N_{\mathrm{CCN}, 0.7 \%}, N_{\mathrm{CCN}, 0.7 \%}$ and

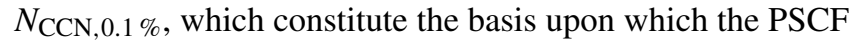
analysis was done, are 466, 184, 268 and 13, respectively. High values in the maps in Fig. 11 indicate which regions have a high potential to contribute to the $25 \%$ of the highest number concentrations measured at the receptor site. The PSCF of $N_{\mathrm{CN}}$ shows enhanced values over the region of the Southern Ocean, mostly between 60 and $40^{\circ} \mathrm{S}$, but not over the Antarctic continental region. Hence, the Southern Ocean is likely to be the dominant source region leading to an enhancement in $N_{\mathrm{CN}}$ measured at PE, while the Antarctic continent itself is not likely to act as a particle source. This is in accordance with results discussed in Sect. 3.1, i.e., the low variability of measured number concentrations during CEs and the occurrence of high values of $N_{\mathrm{CN}}$ observed for air masses connected to MEs.
$N_{\mathrm{CN}}-N_{\mathrm{CCN}, 0.7 \%}$ and $N_{\mathrm{CCN}, 0.7 \%}$ are two complementary parameters, adding up to $N_{\mathrm{CN}}$. The PSCF maps of $N_{\mathrm{CCN}, 0.7 \%}$ and $N_{\mathrm{CN}}-N_{\mathrm{CCN}, 0.7 \%}$ show clearly distinct patterns, indicating that different source regions are likely to contribute to high concentrations of particles with sizes below and above $\approx 35 \mathrm{~nm}$. However, both share that their highest signals are again in the Southern Ocean between 60 and $40^{\circ} \mathrm{S}$, though at different longitudes. The PSCF of $N_{\mathrm{CN}}-N_{\mathrm{CCN}, 0.7 \%}$ (particles with sizes below $\approx 35 \mathrm{~nm}$ ) shows a large area of high signals between $40^{\circ} \mathrm{W}$ and $60^{\circ} \mathrm{E}$. When calculating transport times based on air mass back trajectories, an average transport time of 5.1 days from this area to PE station is obtained. The PSCF of $N_{\mathrm{CCN}, 0.7 \%}$ (particles with sizes above $\approx 35 \mathrm{~nm}$ ) shows the largest area of high signals in a region between 140 and $80^{\circ} \mathrm{W}$ for which the average transport time to the PE station is 8.8 days. These air masses usually travel either along the West Wind Drift, through the Drake Passage, and circumnavigate Antarctica before making landfall close to PE station, or they travel along the easterly winds over coastal East Antarctica until they reach the PE station. This is consistent with the predominance of the easterly wind component during synoptically driven MEs (Gorodetskaya et al., 2013; Souverijns et al., 2018). As already discussed in Sect. 3.1, the aerosol observed at the PE station features a dominant Aitken mode. This can be brought in line with the results discussed here. The aerosol particles that originate from the marine areas that show up dominantly in the PSCF are likely mainly secondary aerosol particles that grow during the transport to the PE station. The size of the measured aerosol particles can be assumed to be a function of average transport time, cor- 
responding to source regions for larger particles that are further away (when considering air mass traveling times). While we assume, with this interpretation, that the source regions are those regions where NPF may have taken place, gaseous precursors may have been emitted in these regions, too, or may have been transported over a distance. Still, our analysis clearly indicates that the Southern Ocean region is a region potentially acting as a source of the majority of particles observed at PES.

The PSCF map for $N_{\mathrm{CCN}, 0.1 \%}$ differs from the others. Overall, values are lower, pointing towards a more uniformly distributed origin of particles with sizes above $\approx 110 \mathrm{~nm}$. But it should also be stressed that values for $N_{\mathrm{CCN}, 0.1 \%}$ are generally low (see Table 2). The PSCF map shows almost no areas of enhanced values over the Southern Ocean, but several spots of comparably enhanced values show up along the coast of Antarctica, i.e., over the Productive Zone region. The overlap between these spots and the different shelf ice areas that are shown in Fig. 1d is noteworthy. The PSCF shows significantly increased values at the locations of the Ross, Filchner-Ronne and Amery shelf ice $(1,2$ and 6 in Fig. 1d) and slightly increased values at the location of the Fimbul, West and Shackleton shelf ice (5, 7 and 8). Hence, the Antarctic shelf ice regions seem to be potential source regions for enhanced values of $N_{\mathrm{CCN}, 0.1 \%}$. We will elaborate on that further in the next section.

\subsection{Hygroscopicity}

For the data set presented here, the hygroscopicity parameter $\kappa$ can only be inferred for $\mathrm{SS}=0.1 \%$, for which the median $d_{\text {crit }}$ was determined to be $110 \mathrm{~nm}$. For higher SSs, $N_{\mathrm{CCN}}$ is above $N_{\mathrm{CN}>90 \mathrm{~nm}}$, i.e., $d_{\text {crit }}$ is below the lower size limit of the measured PNSDs. Therefore, the hygroscopicity derived here is only valid for the low number of comparably large particles that are activated at $0.1 \%$ (see Table 2). All $\kappa$ values from the three seasons have a median value of 1 and are shown in a histogram in Fig. 12. These are generally high atmospheric $\kappa$ values covering a broad range between 0.5 and 1.6. A separate analysis of $\kappa$ for CEs and MEs results in $0.99 \pm 0.18$ (to which $64 \%$ of all separate $\kappa$ values contribute) and $1.05 \pm 0.20$, respectively. There is no clear difference in hygroscopicity of the large particles of roughly $110 \mathrm{~nm}$ analyzed here, independent of the time the air mass had been over the continent. This points towards common sources of these large particles for both CEs and MEs, which are discussed in the following.

Large $\kappa$ values such as those observed here are typically only found for particles consisting of inorganic substances (Petters and Kreidenweis, 2007). Particularly, values of roughly 1 or above are only known to occur for sea salt. 0.95 was reported in Wex et al. (2010) as the mean value for the sea spray signal in marine air masses, derived from a collection of ambient hygroscopic growth measurements. Zieger et al. (2017) give values of 1.1 and 1.5 for inorganic

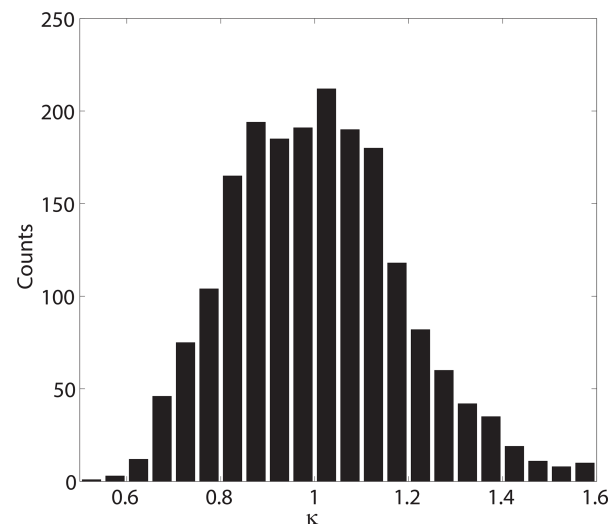

Figure 12. Histogram showing the $2171 \kappa$ values of all three seasons, derived for an SS of $0.1 \%$, for which the median $d_{\text {crit }}$ was determined to be $110 \mathrm{~nm}$. In total, these $\kappa$ values amount to data from roughly $600 \mathrm{~h}$ of measurements.

sea salt and $\mathrm{NaCl}$ particles at $90 \%$ relative humidity, respectively, and Petters and Kreidenweis (2007) give mean values of 1.12 and 1.28 for $\mathrm{NaCl}$, based on hygroscopic growth and $\mathrm{CCN}$ measurements, respectively. While there is discrepancy in the value for $\mathrm{NaCl}$ in literature, it may be worth noting that $\kappa$ derived from hygroscopic growth typically is below that derived from CCN measurements (see Petters and Kreidenweis, 2007). The lower values we derived for $\kappa$ are too low to originate from pure sea salt particles. In addition to inorganic compounds, marine aerosol particles may also contain internally mixed organic substances which reduce their hygroscopicity (Swietlicki et al., 2008). Secondarily formed aerosol particles of marine origin are a result of DMS oxidation and further reactions. They can be expected to contain sulfates, and Petters and Kreidenweis (2007) give a $\kappa$ value of 0.61 for ammonium sulfate, derived from $\mathrm{CCN}$ measurements. Overall, the range of $\kappa$ values we derived for particles with sizes of $\approx 110 \mathrm{~nm}$ indicates that they are mostly composed of inorganic substances. While the lowest $\kappa$ values we determined point towards a contribution of sulfate containing particles in the particle size range examined here of around $110 \mathrm{~nm}$, the median $\kappa$ of 1 might even point towards a dominance of sea salt. This agrees with sea spray particles being generally larger in size, compared to particles formed during NPF and growth, so they might contribute to particles in this size range. It also agrees with an observation made at the Aboa research station, where sodium chloride was found for larger particles with sizes above $100 \mathrm{~nm}$ (Teinila et al., 2000).

Before we compare our results to literature, we want to mention that the uncertainty of the $\kappa$ values was inferred with a method based on Monte Carlo simulations as described in Herenz et al. (2018) and Kristensen et al. (2016). In this approach, uncertainties of input parameters needed for the calculation of $\kappa$ are combined, namely the uncertainties for particle sizing and counting as well as for the SS adjusted in the CCNC. During Monte Carlo simulations, these parameters 
are randomly varied within their uncertainty range during a large number of separate runs (10000 runs in this study) to yield the uncertainty of the derived $\kappa$ based on the uncertainty of the input parameters. This analysis shows that the uncertainties in our $\kappa$ values are in the same order of the variability of the values itself, i.e., the uncertainty in the derived $\kappa$ values can be explained based on measurement uncertainties. This allows no interpretation of the variability in $\kappa$ with respect to different air mass origins.

A few other studies already examined the hygroscopicity of Antarctic aerosol particles as well as the impact of sea ice regions on it. During the PEGASO ship cruise that took place in the austral summer in 2015 in the proximity of the Antarctic Peninsula and the Filchner-Ronne ice shelf, Dall'Osto et al. (2017) found increased $N_{\mathrm{CN}}$ (aerosol particles larger than $3 \mathrm{~nm}$ ) in air masses with an origin over sea ice regions in comparison to air masses that originated over open water. Other studies further suggest that sea ice regions efficiently emit sea salt aerosol particles, e.g., Huang and Jaeglé (2017), Yang et al. (2008) and Wagenbach et al. (1998). O'Shea et al. (2017) measured CCN at the Halley research station, $\approx 30 \mathrm{~km}$ from the Weddell Sea on the Brunt Ice Shelf. They report a median $\kappa$ value of 0.66 during measurements in December for five different SSs $(0.08 \%, 0.2 \%$, $0.32 \%, 0.41 \%, 0.53 \%$ ). Also, they had an event of a median $\kappa$ value of 1.13 during the 2 days when back trajectories indicate that air masses had passed over sea ice regions of the Weddell Sea. This is indicative of ice surfaces being able to emit aerosol particles with a high hygroscopicity and is in line with our findings. Pringle et al. (2010) applied the ECHAM - MESSy Atmospheric Chemistry (EMAC) model to simulate the global distribution of $\kappa$ at the surface. That study results in values between 0.6 and 0.9 for Antarctic coastal areas and $>0.9$ for the Southern Ocean region. Asmi et al. (2010) measured the hygroscopicity of Antarctic aerosol particles at the Aboa station using a HygroscopicityTandem Differential Mobility Analyser. They also found the Antarctic aerosol particles to be very hygroscopic, with an average hygroscopic growth factor of $1.63,1.67$ and 1.75 for 25,50 and $90 \mathrm{~nm}$ particles, respectively, at $90 \% \mathrm{RH}$, which is similar to the hygroscopic growth factor of ammonium sulfate particles at $90 \% \mathrm{RH}$ (given as 1.64, 1.68 and 1.71 for these three different sizes in Asmi et al., 2010). Unlike these studies and our findings, Kim et al. (2017) report a lower particle hygroscopicity. Their results are based on CCN and PNSD measurements that were conducted at the King Sejong Station in the Antarctic Peninsula between 2009 and 2015. For CCN measurements at an SS of $0.4 \%$ they found an annual mean $\kappa$ value of $0.15 \pm 0.05$, which, however, is the only time such low $\kappa$ values were reported for Antarctica.

Summarizing, we conclude that the few large aerosol particles we observe for sizes of $\approx 110 \mathrm{~nm}$ and above may partially originate from NPF and subsequent growth. In this respect, it should also be explicitly mentioned that cloud processing of particles also adds mass to those particles that are activated to cloud droplets (Ervens et al., 2018, and references therein), potentially aiding the growth of particles formed by NPF into the size range discussed here. However, particulate mass added during cloud processing will not have $\kappa$ values above these of sulfates. Therefore, the majority of these aerosol particles in the size range of $\approx 110 \mathrm{~nm}$ likely consist of sea spray particles originating from the open ocean or of sea salt particles emitted over sea ice regions, a statement we base on their comparably high $\kappa$ values. This fits the results presented for $N_{\mathrm{CCN}, 0.1 \%}$ in Sect. 3.2, showing the marine areas in coastal proximity, and especially the shelf ice regions, as potential source regions.

\section{Summary and conclusions}

The data set presented here contains in situ ground-based aerosol particle data sampled at the Belgian Antarctic research station Princess Elisabeth (PE) in Dronning Maud Land in East Antarctica. During three austral summer seasons (2013-2016, each from December to February) we measured total aerosol particle number concentration and size distribution as well as the total CCN number concentration at five different SSs. An automatic weather station, located in the vicinity of the PE station, and a precipitation radar were used to gain further information about the meteorological conditions. The history of the air masses arriving at the PE station was modeled using the NAME dispersion model and the PSCF model based on HYSPLIT back trajectories.

$N_{\mathrm{CN}}$ was found to range between 40 and $6700 \mathrm{~cm}^{-3}$, with a median of $333 \mathrm{~cm}^{-3}$. For particles larger than $90 \mathrm{~nm}\left(N_{\mathrm{CN}>90 \mathrm{~nm}}\right)$ we found a median concentration of $20 \mathrm{~cm}^{-3} . N_{\mathrm{CCN}}$ covers a range between less than $10 \mathrm{~cm}^{-3}$ at $\mathrm{SS}=0.1 \%$ and $1300 \mathrm{~cm}^{-3}$ for the highest SS of $0.7 \%$. The median values of $N_{\mathrm{CCN}}$ for SSs of $0.1 \%, 0.2 \%, 0.3 \%$, $0.5 \%$ and $0.7 \%$ are $14,81,121,177$ and $212 \mathrm{~cm}^{-3}$, respectively. All of the previous values are calculated on the basis of the entire measurement period of three austral summers. The ratios of $N_{\mathrm{CN}>90 \mathrm{~nm}} / N_{\mathrm{CN}}$ and $N_{\mathrm{CCN}, 0.7 \%} / N_{\mathrm{CN}}$ indicate that $94 \%$ and $36 \%$ of the particles are smaller than 90 and $\approx 35 \mathrm{~nm}$, respectively. From this, we conclude that an aerosol dominated by the Aitken mode prevailed, which likely includes a significant amount of secondarily formed aerosol particles.

The fluctuations in $N_{\mathrm{CN}}$ and $N_{\mathrm{CCN}}$ can be associated with the history of the air masses and the precipitation measured at the PE station. Both methods, the regional analysis on the basis of the NAME dispersion model as well as the PSCF analysis, show that high $N_{\mathrm{CN}}$ values are directly linked to the advection of marine air masses, which we call marine events (MEs), having their origin in the region of the Southern Ocean. The occurrence of precipitation is also directly linked to the occurrence of MEs, as marine air masses are the only significant source of water vapor in Antarctica. Strong precipitation events caused the lowest 
$N_{\mathrm{CN}}$ and $N_{\mathrm{CCN}}$ values presented in this study, due to particle scavenging and wet deposition. Therefore, MEs showed the lowest but also the highest particle concentrations measured. In contrast, when air masses had spent more than $90 \%$ of the 10 days prior to arrival over the Antarctic continent, which are times we called continental events (CEs), measured $N_{\mathrm{CN}}$ and $N_{\mathrm{CCN}}$ values were comparably constant, and we assume these to be continental background concentrations during the austral summer. The Antarctic continent itself was found not to act as a significant source of aerosol particles and the $\mathrm{CCN}$ measured at the PE station during these times. MEs and CEs occur $39 \%$ and $61 \%$ of the time, respectively.

The hygroscopicity of the CCNs could only be determined for measurements at $\mathrm{SS}=0.1 \%$, as the PNSDs could only be measured in a size range between $90 \mathrm{~nm}$ and $6.8 \mu \mathrm{m}$. The median $d_{\text {crit }}$ and $\kappa$ of the entire measurement period were determined to be $110 \mathrm{~nm}$ and 1 , respectively. This high hygroscopicity, which is valid for the comparably small fraction of particles observed in the respective size range, is in agreement with most of the other studies dealing with Antarctic hygroscopicity and can be attributed to the presence of mainly sea salt and likely, but to a minor degree, sulfate aerosol particles. This is in agreement with the PSCF analysis for which the Antarctic ice shelf areas were found to cause elevated values for particles with sizes above $\approx 110 \mathrm{~nm}$, again pointing to sea salt aerosol particles. These particles could have been released and formed from snow particles from surface snow layers, e.g., during periods of high wind speed when fresh snow is available and winds are high enough to cause drifting or blowing snow (Gossart et al., 2017), or may otherwise originate from sea spray directly.

Although this is, to our knowledge, the most comprehensive set of CCN data in the region of East Antarctica, it is limited to the austral summer seasons. For a complete picture of $\mathrm{CCN}$ properties in East Antarctica, measurements throughout the whole year are needed, together with PNSD measurements covering diameters down to a few nanometers. This would enable more in-depth investigations of NPF and particle hygroscopicity in different size ranges. However, the data presented here increase our knowledge of aerosol particles and, in particular, $\mathrm{CCN}$ properties in Antarctica.

Data availability. Data is made available at Pangaea: https://doi. pangaea.de/10.1594/PANGAEA.894841 (Herenz et al., 2019). Additionally, data from the instrumentation at the Princess Elisabeth station can be obtained from the database on http://www.aerocloud. be.

Author contributions. $\mathrm{PH}$ and $\mathrm{HW}$ calibrated the CCNC prior to each season at TROPOS. AM generally cared for and operated all aerosol instrumentation at PES and analyzed data from the LAS and the CPC. IG installed and managed operation of the automatic weather station and precipitation radar at PES, and evaluated and analyzed the precipitation data. QL operated the instruments at PES during one season. ZF and MP operated the NAME model and created the regional divisions using GIS and the respective data analysis from this. $\mathrm{PH}$ analyzed the $\mathrm{CCNC}$ data, collected and combined all data and did the PSCF analysis. PH, SF and HW intensely discussed the interpretation of the data on many occasions. $\mathrm{PH}$ wrote the paper and HW attended to the reviews, both with contributions from all co-authors.

Competing interests. The authors declare that they have no conflict of interest.

Special issue statement. This article is part of the special issue "BACCHUS - Impact of Biogenic versus Anthropogenic emissions on Clouds and Climate: towards a Holistic UnderStanding (ACP/AMT/GMD inter-journal SI)". It is not associated with a conference.

Acknowledgements. This work was funded by the EU FP7ENV-2013 program "Impact of Biogenic vs. Anthropogenic emissions on Clouds and Climate: towards a Holistic UnderStanding" (BACCHUS), project number 603445, and by the Belgian Science Policy Office under contract EA/34/1B and under grant number BR/143/A2/AEROCLOUD. We thank Wim Boot, Carleen Reijmer and Michiel Van den Broeke (Utrecht University, Institute for Marine and Atmospheric Research, the Netherlands), and Alexandra Gossart and Nicole van Lipzig (KU Leuven) for the data from the Automatic Weather Station. We also thank Niels Souverijns and Nicole van Lipzig (KU Leuven) for the provision of the precipitation data. The authors acknowledge the NOAA Air Resources Laboratory (ARL) for the provision of the HYSPLIT transport and dispersion model and would like to thank the UK Meteorological Office for the use of the NAME dispersion model and the STFC JASMIN computer for hosting the model.

Edited by: Paul Zieger

Reviewed by: three anonymous referees

\section{References}

Albrecht, B.: Aerosols, cloud microphysics, and fractional cloudiness, Science, 245, 1227-1230, 1989.

Ashbaugh, L. L., Malm, W. C., and Sadeh, W. Z.: A residence time probability analysis of sulfur concentrations at grand Canyon National Park, Atmos. Environ., 19, 1263-1270, https://doi.org/10.1016/0004-6981(85)90256-2, 1985.

Asmi, E., Frey, A., Virkkula, A., Ehn, M., Manninen, H. E., Timonen, H., Tolonen-Kivimäki, O., Aurela, M., Hillamo, R., and Kulmala, M.: Hygroscopicity and chemical composition of Antarctic sub-micrometre aerosol particles and observations of new particle formation, Atmos. Chem. Phys., 10, 4253-4271, https://doi.org/10.5194/acp-10-4253-2010, 2010.

Carslaw, K., Lee, L., Reddington, C., Pringle, K., Rap, A., Forster, P., Mann, G., Spracklen, D., Woodhouse, M., Regayre, L., et al.: 
Large contribution of natural aerosols to uncertainty in indirect forcing, Nature, 503, 67-71, 2013.

Dall'Osto, M., Ovadnevaite, J., Paglione, M., Beddows, D. C., Ceburnis, D., Cree, C., Cortés, P., Zamanillo, M., Nunes, S. O., Pérez, G. L., Ortega-Retuerta, E., Emelianov, M., Vaque, D., Marrase, C., Estrada, M., Sala, M. M., Vidal, M., Fitzsimons, M. F., Beale, R., Airs, R., Rinaldi, M., Decesari, S., Facchini, M. C., Harrison, R. M., O’Dowd, C., and Simo, R.: Antarctic sea ice region as a source of biogenic organic nitrogen in aerosols, Sci. Rep., 7, 6047, https://doi.org/10.1038/s41598-017-06188-x, 2017.

DeFelice, T.: Variations in cloud condensation nuclei at palmer station Antarctica during February 1994, Atmos. Res., 41, 229-248, 1996.

DeFelice, T., Saxena, V., and Yu, S.: On the measurements of cloud condensation nuclei at Palmer Station, Antarctica, Atmos. Environ., 31, 4039-4044, 1997.

Ervens, B., Sorooshian, A., Aldhaif, M., Shingler, T., Crosbie, E., Ziemba, L., Campuzano-Jost, P., Jimenez, J. L., and Wisthaler, A.: Is there an aerosol signature of cloud processing?, Atmos. Chem. Phys., 18, 16099-16119, https://doi.org/10.5194/acp-1816099-2018, 2018.

Fiebig, M., Hirdman, D., Lunder, C. R., Ogren, J. A., Solberg, S., Stohl, A., and Thompson, R. L.: Annual cycle of Antarctic baseline aerosol: controlled by photooxidationlimited aerosol formation, Atmos. Chem. Phys., 14, 3083-3093, https://doi.org/10.5194/acp-14-3083-2014, 2014.

Fleming, Z. L., Monks, P. S., and Manning, A. J.: Review: Untangling the influence of air-mass history in interpreting observed atmospheric composition, Atmos. Res., 104-105, 1-39, https://doi.org/10.1016/j.atmosres.2011.09.009, 2012.

Gorodetskaya, I. V., Van Lipzig, N. P. M., Van den Broeke, M. R., Mangold, A., Boot, W., and Reijmer, C. H.: Meteorological regimes and accumulation patterns at Utsteinen, Dronning Maud Land, East Antarctica: Analysis of two contrasting years, J. Geophys. Res.-Atmos., 118, 1700-1715, https://doi.org/10.1002/jgrd.50177, 2013.

Gorodetskaya, I. V., Tsukernik, M., Claes, K., Ralph, M. F., Neff, W. D., and Van Lipzig, N. P. M.: The role of atmospheric rivers in anomalous snow accumulation in East Antarctica, Geophys. Res. Lett., 41, 6199-6206, https://doi.org/10.1002/2014gl060881, 2014.

Gorodetskaya, I. V., Kneifel, S., Maahn, M., Van Tricht, K., Thiery, W., Schween, J. H., Mangold, A., Crewell, S., and Van Lipzig, N. P. M.: Cloud and precipitation properties from ground-based remote-sensing instruments in East Antarctica, The Cryosphere, 9, 285-304, https://doi.org/10.5194/tc-9-285-2015, 2015.

Gossart, A., Souverijns, N., Gorodetskaya, I. V., Lhermitte, S., Lenaerts, J. T. M., Schween, J. H., Mangold, A., Laffineur, Q., and van Lipzig, N. P. M.: Blowing snow detection from ground-based ceilometers: application to East Antarctica, The Cryosphere, 11, 2755-2772, https://doi.org/10.5194/tc-11-27552017, 2017.

Greene, C. A., Gwyther, D. E., and Blankenship, D. D.: Antarctic Mapping Tools for Matlab, Comput. Geosci., 104, 151-157, https://doi.org/10.1016/j.cageo.2016.08.003, 2017.

Gysel, M. and Stratmann, F.: WP3 - NA3: In-situ chemical, physical and optical properties of aerosols, Deliverable D3.11: Standardized protocol for CCN measurements, Tech. rep.,http:
//www.actris.net/Publications/ACTRISQualityStandards/tabid/ 11271/language/en-GB/Default.aspx (last access: 4 January 2019), 2013.

Hamilton, D. S., Lee, L. A., Pringle, K. J., Reddington, C. L., Spracklen, D. V., and Carslaw, K. S.: Occurrence of pristine aerosol environments on a polluted planet, P. Natl. Acad. Sci. USA, 111, 18466-18471, https://doi.org/10.1073/pnas.1415440111, 2014.

Hara, K., Osada, K., Nishita-Hara, C., and Yamanouchi, T.: Seasonal variations and vertical features of aerosol particles in the Antarctic troposphere, Atmos. Chem. Phys., 11, 5471-5484, https://doi.org/10.5194/acp-11-5471-2011, 2011.

Herenz, P., Wex, H., Henning, S., Kristensen, T. B., Rubach, F., Roth, A., Borrmann, S., Bozem, H., Schulz, H., and Stratmann, F.: Measurements of aerosol and CCN properties in the Mackenzie River delta (Canadian Arctic) during spring-summer transition in May 2014, Atmos. Chem. Phys., 18, 4477-4496, https://doi.org/10.5194/acp-18-4477-2018, 2018.

Herenz, P., Wex, H., Mangold, A., Laffineur, Q., Gorodetskaya, I. V., Flemming, Z. L., Panagi, M., and Stratmann, F.: Meteorological observations and condensation nuclei measurements at the Princess Elisabeth Antarctica Research Station during three austral summers, PANGAEA, https://doi.org/10.1594/PANGAEA.894841, 2019.

Hopke, P. K.: Review of receptor modeling methods for source apportionment, J. Air Waste Manage. Assoc., 66, 237-259, https://doi.org/10.1080/10962247.2016.1140693, 2016.

Huang, J. and Jaeglé, L.: Wintertime enhancements of sea salt aerosol in polar regions consistent with a sea ice source from blowing snow, Atmos. Chem. Phys., 17, 3699-3712, https://doi.org/10.5194/acp-17-3699-2017, 2017.

IPCC: Climate Change 2013: The Physical Science Basis, in: Contribution of Working Group I to the Fifth Assessment Report of the Intergovernmental Panel on Climate Change, Cambridge University Press, Cambridge, UK and New York, NY, USA, https://doi.org/10.1017/CBO9781107415324, 2013.

Jacka, T. and Budd, W.: Detection of temperature and sea-ice-extent changes in the Antarctic and Southern Ocean, 1949-96, Ann. Glaciol., 27, 553-559, 1998.

Järvinen, E., Virkkula, A., Nieminen, T., Aalto, P. P., Asmi, E., Lanconelli, C., Busetto, M., Lupi, A., Schioppo, R., Vitale, V., Mazzola, M., Petäjä, T., Kerminen, V.-M., and Kulmala, M.: Seasonal cycle and modal structure of particle number size distribution at Dome C, Antarctica, Atmos. Chem. Phys., 13, 7473-7487, https://doi.org/10.5194/acp-13-7473-2013, 2013.

Jones, A., Thomson, D., Hort, M., and Devenish, B.: The U.K. Met Office's Next-Generation Atmospheric Dispersion Model, NAME III, Springer US, Boston, MA, 580-589, https://doi.org/10.1007/978-0-387-68854-1_62, 2007.

Kim, J., Yoon, Y. J., Gim, Y., Kang, H. J., Choi, J. H., Park, K.-T., and Lee, B. Y.: Seasonal variations in physical characteristics of aerosol particles at the King Sejong Station, Antarctic Peninsula, Atmos. Chem. Phys., 17, 12985-12999, https://doi.org/10.5194/acp-17-12985-2017, 2017.

Koponen, I. K., Virkkula, A., Hillamo, R., Kerminen, V. M., and Kulmala, M.: Number size distributions and concentrations of the continental summer aerosols in Queen Maud Land, Antarctica, J. Geophys. Res., 108, 4587, https://doi.org/10.1029/2003jd003614, 2003. 
Kravchenko, V., Evtushevsky, O., Grytsai, A., and Milinevsky, G.: Decadal variability of winter temperatures in the Antarctic Peninsula region, Antarct. Sci., 23, 614-622, 2011.

Kristensen, T. B., Müller, T., Kandler, K., Benker, N., Hartmann, M., Prospero, J. M., Wiedensohler, A., and Stratmann, F.: Properties of cloud condensation nuclei $(\mathrm{CCN})$ in the trade wind marine boundary layer of the western North Atlantic, Atmos. Chem. Phys., 16, 2675-2688, https://doi.org/10.5194/acp-162675-2016, 2016.

Kyrö, E M., Kerminen, V. M., Virkkula, A., Dal Maso, M., Parshintsev, J., Ruiz-Jimenez, J., Forsstrom, L., Manninen, H. E., Riekkola, M. L., Heinonen, P., and Kulmala, M.: Antarctic new particle formation from continental biogenic precursors, Atmos. Chem. Phys., 13, 3527-3546, https://doi.org/10.5194/acp13-3527-2013, 2013.

Lamb, D. and Verlinde, J.: Physics and chemistry of clouds, Cambridge University Press, Cambridge, 2011.

Legrand, M., Ducroz, F., Wagenbach, D., Mulvaney, R., and Hall, J.: Ammonium in coastal Antarctic aerosol and snow: Role of polar ocean and penguin emissions, J. Geophys. Res.-Atmos., 103, 11043-11056, https://doi.org/10.1029/97JD01976, 1998.

Liss, P. S. and Lovelock, J. E.: Climate change: the effect of DMS emissions, Environ. Chem., 4, 377-378, 2008.

Maahn, M. and Kollias, P.: Improved Micro Rain Radar snow measurements using Doppler spectra post-processing, Atmos. Meas. Tech., 5, 2661-2673, https://doi.org/10.5194/amt-5-2661-2012, 2012.

Martin-Español, A., Bamber, J. L., and Zammit-Mangion, A.: Constraining the mass balance of East Antarctica, Geophys. Res. Lett., 44, 4168-4175, https://doi.org/10.1002/2017GL072937, 2017.

Meskhidze, N. and Nenes, A.: Phytoplankton and cloudiness in the southern ocean, Science, 314, 1419-1423, https://doi.org/10.1126/science.1131779, 2006.

Modini, R. L., Frossard, A. A., Ahlm, L., Russell, L. M., Corrigan, C. E., Roberts, G. C., Hawkins, L. N., Schroder, J. C., Bertram, A. K., Zhao, R., Lee, A. K. Y., Abbatt, J. P. D., Lin, J., Nenes, A., Wang, Z., Wonaschütz, A., Sorooshian, A., Noone, K. J., Jonsson, H., Seinfeld, J. H., Toom-Sauntry, D., Macdonald, A. M., and Leaitch, W. R.: Primary marine aerosol-cloud interactions off the coast of California, J. Geophys. Res.-Atmos., 120, 42824303, https://doi.org/10.1002/2014JD022963, 2015.

O'Shea, S. J., Choularton, T. W., Flynn, M., Bower, K. N., Gallagher, M., Crosier, J., Williams, P., Crawford, I., Fleming, Z. L., Listowski, C., Kirchgaessner, A., Ladkin, R. S., and Lachlan-Cope, T.: In situ measurements of cloud microphysics and aerosol over coastal Antarctica during the MAC campaign, Atmos. Chem. Phys., 17, 13049-13070, https://doi.org/10.5194/acp-17-13049-2017, 2017.

Parkinson, C. L. and Cavalieri, D. J.: Antarctic sea ice variability and trends, 1979-2010, The Cryosphere, 6, 871-880, https://doi.org/10.5194/tc-6-871-2012, 2012.

Parkinson, C. L. and Cavalieri, D. J.: Antarctic sea ice variability and trends, 1979-2010, The Cryosphere, 6, 871-880, https://doi.org/10.5194/tc-6-871-2012, 2012.

Pattyn, F., Matsuoka, K., and Berte, J.: Glacio-meteorological conditions in the vicinity of the Belgian Princess Elisabeth Station, Antarctica, Antarctic Sci., 1, 79-85, https://doi.org/10.1017/S0954102009990344, 2010.
Petters, M. D. and Kreidenweis, S. M.: A single parameter representation of hygroscopic growth and cloud condensation nucleus activity, Atmos. Chem. Phys., 7, 1961-1971, https://doi.org/10.5194/acp-7-1961-2007, 2007.

Pringle, K. J., Tost, H., Pozzer, A., Pöschl, U., and Lelieveld, J.: Global distribution of the effective aerosol hygroscopicity parameter for CCN activation, Atmos. Chem. Phys., 10, 52415255, https://doi.org/10.5194/acp-10-5241-2010, 2010.

Quinn, P. K., Coffman, D. J., Johnson, J. E., Upchurch, L. M., and Bates, T. S.: Small fraction of marine cloud condensation nuclei made up of sea spray aerosol, Nat. Geosci., 10, 674-679, https://doi.org/10.1038/ngeo3003, 2017.

Roberts, G. C. and Nenes, A.: A continuous-flow streamwise thermal-gradient $\mathrm{CCN}$ chamber for atmospheric measurements, Aerosol Sci. Tech., 39, 206-221, https://doi.org/10.1080/027868290913988, 2005.

Rose, D., Gunthe, S. S., Mikhailov, E., Frank, G. P., Dusek, U., Andreae, M. O., and Pöschl, U.: Calibration and measurement uncertainties of a continuous-flow cloud condensation nuclei counter (DMT-CCNC): CCN activation of ammonium sulfate and sodium chloride aerosol particles in theory and experiment, Atmos. Chem. Phys., 8, 1153-1179, https://doi.org/10.5194/acp8-1153-2008, 2008.

Rosenfeld, D., Lohmann, U., Raga, G. B., O’Dowd, C. D., Kulmala, M., Fuzzi, S., Reissell, A., and Andreae, M. O.: Flood or drought: How do aerosols affect precipitation?, Science, 321, 1309-1313, https://doi.org/10.1126/science.1160606, 2008.

Schaffer, J., Timmermann, R., Arndt, J. E., Kristensen, S. S., Mayer, C., Morlighem, M., and Steinhage, D.: A global, highresolution data set of ice sheet topography, cavity geometry, and ocean bathymetry, Earth Syst. Sci. Data, 8, 543-557, https://doi.org/10.5194/essd-8-543-2016, 2016.

Schmale, J., Schneider, J., Nemitz, E., Tang, Y. S., Dragosits, U., Blackall, T. D., Trathan, P. N., Phillips, G. J., Sutton, M., and Braban, C. F.: Sub-Antarctic marine aerosol: dominant contributions from biogenic sources, Atmos. Chem. Phys., 13, 86698694, https://doi.org/10.5194/acp-13-8669-2013, 2013.

Shepherd, A., Ivins, E. R., Geruo, A., Barletta, V. R., Bentley, M. J., Bettadpur, S., Briggs, K. H., Bromwich, D. H., Forsberg, R., Galin, N., Horwath, M., Jacobs, S., Joughin, I., King, M. A., Lenaerts, J. T., Li, J., Ligtenberg, S. R., Luckman, A., Luthcke, S. B., McMillan, M., Meister, R., Milne, G., Mouginot, J., Muir, A., Nicolas, J. P., Paden, J., Payne, A. J., Pritchard, H., Rignot, E., Rott, H., Sørensen, L. S., Scambos, T. A., Scheuchl, B., Schrama, E. J., Smith, B., Sundal, A. V., van Angelen, J. H., van de Berg, W. J., van den Broek,e M. R., Vaughan, D. G., Velicogna, I., Wahr, J., Whitehouse, P. L., Wingham, D. J., Yi, D., Young, D., and Zwally, H. J.: A reconciled estimate of ice-sheet mass balance, Science, 338, 1183-1189, 2012.

Shepherd, A., Ivins, E., Rignot, E., Smith, B., van den Broeke, M., Velicogna, I., Whitehouse, P., Briggs, K., Joughin, I., Krinner, G., Nowicki, S., Payne, T., Scambos, T., Schlegel, N., Geruo, A., Agosta, C., Ahlstrom, A., Babonis, G., Barletta, V., Blazquez, A., Bonin, J., Csatho, B., Cullather, R., Felikson, D., Fettweis, X., Forsberg, R., Gallee, H., Gardner, A., Gilbert, L., Groh, A., Gunter, B., Hanna, E., Harig, C., Helm, V., Horvath, A., Horwath, M., Khan, S., Kjeldsen, K. K., Konrad, H., Langen, P., Lecavalier, B., Loomis, B., Luthcke, S., McMillan, M., Melini, D., Mernild, S., Mohajerani, Y., Moore, P., Mouginot, J., Moy- 
ano, G., Muir, A., Nagler, T., Nield, G., Nilsson, J., Noel, B., Otosaka, I., Pattle, M. E., Peltier, W. R., Pie, N., Rietbroek, R., Rott, H., Sandberg-Sorensen, L., Sasgen, I., Save, H., Scheuchl, B., Schrama, E., Schroder, L., Seo, K. W., Simonsen, S., Slater, T., Spada, G., Sutterley, T., Talpe, M., Tarasov, L., van de Berg, W. J., van der Wal, W., van Wessem, M., Vishwakarma, B. D., Wiese, D., Wouters, B., and Team, I.: Mass balance of the Antarctic Ice Sheet from 1992 to 2017, Nature, 558, 219-222, https://doi.org/10.1038/s41586-018-0179-y, 2018.

Souverijns, N., Gossart, A., Lhermitte, S., Gorodetskaya, I. V., Kneifel, S., Maahn, M., Bliven, F. L., and van Lipzig, N. P. M.: Estimating radar reflectivity - Snowfall rate relationships and their uncertainties over Antarctica by combining disdrometer and radar observations, Atmos. Res., 196, 211-223, https://doi.org/10.1016/j.atmosres.2017.06.001, 2017.

Souverijns, N., Gossart, A., Gorodetskaya, I. V., Lhermitte, S., Mangold, A., Laffineur, Q., Delcloo, A., and van Lipzig, N. P. M.: How does the ice sheet surface mass balance relate to snowfall? Insights from a ground-based precipitation radar in East Antarctica, The Cryosphere, 12, 1987-2003, https://doi.org/10.5194/tc12-1987-2018, 2018.

Stein, A. F., Draxler, R. R., Rolph, G. D., Stunder, B. J. B., Cohen, M. D., and Ngan, F.: NOAA's HYSPLIT Atmospheric Transport and Dispersion Modeling System, B. Am. Meteorol. Soc., 96, 2059-2077, https://doi.org/10.1175/BAMS-D-14$00110.1,2015$.

Swietlicki, E., Hansson, H.-C., Hämeri, K., Svenningsson, B., Massling, A., McFiggans, G., McMurry, P., Petäjä, T., Tunved, P., Gysel, M., Topping, D., Weingartner, E., Baltensperger, U., Rissler, J., Wiedensohler, A., and Kulmala, M.: Hygroscopic properties of submicrometer atmospheric aerosol particles measured with H-TDMA instruments in various environments - A review, Tellus B, 60, 432-469, 2008.

Teinila, K., Kerminen, V. M., and Hillamo, R.: A study of size-segregated aerosol chemistry in the Antarctic atmosphere, J. Geophys. Res.-Atmos., 105, 3893-3904, https://doi.org/10.1029/1999jd901033, 2000.

Twomey, S.: Pollution and the planetary albedo, Atmos. Environ., 8, 1251-1256, 1974.

Vallina, S. M., Simó, R., and Gassó, S.: What controls CCN seasonality in the Southern Ocean? A statistical analysis based on satellite-derived chlorophyll and $\mathrm{CCN}$ and model-estimated $\mathrm{OH}$ radical and rainfall, Global Biogeochem. Cy., 20, gB1014, https://doi.org/10.1029/2005GB002597, 2006.

Vaughan, D. G., Marshall, G. J., Connolley, W. M., Parkinson, C., Mulvaney, R., Hodgson, D. A., King, J. C., Pudsey, C. J., and Turner, J.: Recent Rapid Regional Climate Warming on the Antarctic Peninsula, Climatic Change, 60, 243-274, https://doi.org/10.1023/A:1026021217991, 2003.

Velicogna, I. and Wahr, J.: Measurements of time-variable gravity show mass loss in Antarctica, Science, 311, 1754-1756, 2006.

Virkkula, A., Asmi, E., Teinilä, K., Frey, A., Aurela, M., Timonen, H., Mäkelä, T., Samuli, A., Hillamo, R., Aalto, P. P., Kirkwood, S., and Kulmala, M.: Review of aerosol research at the Finnish antarctic research station Aboa and its surroundings in Queen Maud Land, Antarctica, Geophysica, 45, 163-181, 2009.

Wagenbach, D., Görlach, U., Moser, K., and Münnich, K. O.: Coastal Antarctic aerosol: The seasonal pattern of its chemical composition and radionuclide content, Tellus B, 40, 426-436, https://doi.org/10.3402/tellusb.v40i5.16010, 1988.

Wagenbach, D., Ducroz, F., Mulvaney, R., Keck, L., Minikin, A., Legrand, M., Hall, J., and Wolff, E.: Sea-salt aerosol in coastal Antarctic regions, J. Geophys. Res.-Atmos., 103, 10961-10974, 1998.

Waked, A., Favez, O., Alleman, L. Y., Piot, C., Petit, J.-E., Delaunay, T., Verlinden, E., Golly, B., Besombes, J.-L., Jaffrezo, J.L., and Leoz-Garziandia, E.: Source apportionment of $\mathrm{PM}_{10}$ in a north-western Europe regional urban background site (Lens, France) using positive matrix factorization and including primary biogenic emissions, Atmos. Chem. Phys., 14, 3325-3346, https://doi.org/10.5194/acp-14-3325-2014, 2014.

Wegner, A., Fischer, H., Delmonte, B., Petit, J.-R., Erhardt, T., Ruth, U., Svensson, A., Vinther, B., and Miller, H.: The role of seasonality of mineral dust concentration and size on glacial/interglacial dust changes in the EPICA Dronning Maud Land ice core, J. Geophys. Res.-Atmos., 120, 9916-9931, https://doi.org/10.1002/2015JD023608, 2015.

Weller, R., Minikin, A., Wagenbach, D., and Dreiling, V.: Characterization of the inter-annual, seasonal, and diurnal variations of condensation particle concentrations at Neumayer, Antarctica, Atmos. Chem. Phys., 11, 13243-13257, https://doi.org/10.5194/acp-11-13243-2011, 2011.

Weller, R., Schmidt, K., Teinilä, K., and Hillamo, R.: Natural new particle formation at the coastal Antarctic site Neumayer, Atmos. Chem. Phys., 15, 11399-11410, https://doi.org/10.5194/acp-1511399-2015, 2015.

Wex, H., McFiggans, G., Henning, S., and Stratmann, F.: Influence of the external mixing state of atmospheric aerosol on derived CCN number concentrations, Geophys. Res. Lett., 37, L10805, https://doi.org/10.1029/2010GL043337, 2010.

Wex, H., Dieckmann, K., Roberts, G. C., Conrath, T., Izaguirre, M. A., Hartmann, S., Herenz, P., Schäfer, M., Ditas, F., Schmeissner, T., Henning, S., Wehner, B., Siebert, H., and Stratmann, F.: Aerosol arriving on the Caribbean island of Barbados: Physical properties and origin, Atmos. Chem. Phys., 16, 14107-14130, https://doi.org/10.5194/acp-16-14107-2016, 2016.

WMO: GAW report No. 227, WMO/GAW Aerosol Measurement Procedures, Guidelines and Recommendation, WMONo. 1177, WMO, available at: https://library.wmo.int/index.php? lvl=notice_display\&id=19622 (last access: January 2019), 2016.

Yang, X., Pyle, J. A., and Cox, R. A.: Sea salt aerosol production and bromine release: Role of snow on sea ice, Geophys. Res. Lett., 35, 116815, https://doi.org/10.1029/2008GL034536, 2008.

Yli-Tuomi, T., Hopke, P. K., Paatero, P., Basunia, M., Landsberger, S., Viisanen, Y., and Paatero, J.: Atmospheric aerosol over Finnish Arctic: source analysis by the multilinear engine and the potential source contribution function, Atmos. Environ., 37, 4381-4392, https://doi.org/10.1016/S1352-2310(03)005697, 2003.

Zieger, P., Väisänen, O., Corbin, J., Partridge, D. G., Bastelberger, S., Mousavi-Fard, M., Rosati, B., Gysel, M., Krieger, U., Leck, C., Nenes, A. Riipinen, I., Virtanen, A., and Salter, M. E.: Revising the hygroscopicity of inorganic sea salt particles, Nat. Commun., 8, 15883, https://doi.org/10.1038/ncomms15883, 2017. 